\title{
KAKUCS-BALLA-DOMB \\ A CASE STUDY IN THE ABSOLUTE AND RELATIVE CHRONOLOGY OF THE VATYA CULTURE
}

\author{
M. JAEGER*-G. KULCSÁR** \\ * Adam Mickiewicz University in Poznań, Institute of European Culture \\ ul. Kostrzewskiego 5-7, 62-200 Gniezno, Poland \\ E-mail: jaeger@amu.edu.pl \\ **Hungarian Academy of Sciences, Research Centre for the Humanities, Institute of Archaeology \\ Úri u. 49, H-1014 Budapest, Hungary \\ E-mail: kulcsar.gabriella@btk.mta.hu
}

\begin{abstract}
The present study hopes to contribute to Middle Bronze Age studies in two specific areas: first, by publishing a new series of radiocarbon dates for a period from which there are few absolute dates, and second, by describing a less known area in the Vatya culture distribution based on the investigations at Kakucs.

The Kakucs area was increasingly intensively settled during the course of the Bronze Age. In this context, the area along the left Danube bank down to the Kakucs area, lying in close proximity to the eponymous site at Újhartyán-Vatya, is very instructive. Following a scanty occupation marked by a few smaller sites at the onset of the Early Bronze Age, the number of sites and associated cemeteries grew dynamically from the late Nagyrév/early Vatya period onward. Despite the uncertainties in the relative chronology of the known Middle Bronze Age sites, the increase in the number of sites is in itself a reflection of a population growth and an increasing landscape exploitation. The left bank of the Danube became one of the period's most intensively settled regions during the Middle Bronze Age 1-3.
\end{abstract}

Keywords: Middle Bronze Age, tell settlements, Vatya ceramic style, Kakucs-Balla-domb, ${ }^{14} \mathrm{C}$ chronology, absolute dating

\section{INTRODUCTION}

The settlements and the cemeteries in the central region of Hungary lying along the north to south Danube section are characterised by pottery made in the Vatya style during the Middle Bronze Age. This period corresponds to the RB A1/A2-RB B in the chronological scheme introduced by Paul Reinecke. In terms of absolute chronology, the Vatya sequence spans some 400 to 500 years between 2000/1900 and 1500/1450 BC. ${ }^{1}$ Regarding ceramic styles and typology, this period starts with the Nagyrév/Vatya transition, continues with Vatya I-III and ends with the Koszider period according to the conventional scheme used in Hungarian Bronze Age studies. ${ }^{2}$ Many settlements and cemeteries of the Vatya culture dating from these roughly five hundred years are known from the fundamentally differing environments characterising Northeastern and Eastern Transdanubia, the Danube region and the DanubeTisza interfluve. Several studies have been devoted to the culture's cemeteries, ${ }^{3}$ as well as to the multi-tiered Vatya

${ }^{1}$ RACZKY-HERTELENDI-HORVÁth 1992; for a recent overview see: P. FISCHL et al. in press.

${ }^{2}$ E. g. BÓNA 1975, 31-78; KovÁCS 1984; BÓNA 1992a, 24-26; BÓNA 1992b; REMÉNYI 2005; VICZE 2011.
${ }^{3}$ E. g. BÁNDI 1966; BónA 1975, 31-78; VicZe 1985; ViCZE 1986; VICZE 1992a; KALICZ-SCHREIBER 1995a; SZATHMÁRI 1996; for a good summary, see VICZE 2011. 
settlement network made up of fortified hillforts, stratified tell settlements (Fig. 1) and open settlements. ${ }^{4}$ The period's perhaps best-investigated region is the Százhalombatta area ${ }^{5}$ and the Benta Valley ${ }^{6}$ west of the Danube. The number of known sites has increased manifold as result of continuous field surveys and excavations. The publication of the already investigated sites will no doubt contribute to drawing together the evidence on Vatya settlements and to adding finer details to the broad picture of how Vatya settlements evolved, as well as to the dynamics of their growth and the diachronic changes in settlement patterns.

The present study hopes to contribute to Middle Bronze Age studies in two specific areas: first, by publishing a new series of radiocarbon dates for a period from which there are few absolute dates, and second, by describing a less known area in the Vatya distribution based on the investigations at Kakucs. The environment of the region south of Budapest and east of the Danube was largely determined by the channels of the palaeo-Danube during the successive archaeological and historical periods. ${ }^{7}$ The bluffs overlooking the rivers and the larger islets were dotted with Middle Bronze Age settlements and cemeteries, among them the stratified tell settlements of Balla-domb and Szélmalom-domb on the outskirts of Kakucs, which were probably one of the centres in the settlement network of this region during the earlier $2^{\text {nd }}$ millennium $\mathrm{BC}$.

\section{THE BRONZE AGE LANDSCAPE IN THE KAKUCS AREA}

The study area extends to Dömsöd along the Danube section south of Budapest and is bounded by the Soroksár-Gyál-Kakucs line in the east (Fig. 2). Administratively, the area is part of the southern district of County Pest and it incorporates sections of various micro-regions, among them the southerly alluvial fan of the Pest Plain, the eastern half of the Csepel Plain and, moving further to the east, the Pilis-Alpár sand dunes and the Kiskunság sand dunes of the Danube-Tisza interfluve. ${ }^{8}$ Towards the east, the Csepel Plain gradually rises from the floodplain of the Danube Valley towards the higher-lying terraces (95-168 m a.s.1.), whose eastern margins are covered with alkaline grassland (Apaj) and wind-blown sand (Sári [Dabas], Kunpeszér). Lying farther to the east is the Pest alluvial fan on the northern fringes of the Danube-Tisza interfluve. The area is wedged in-between the Gödöllö Hills and the Csepel Plain (98-251 m a.s.l.). The mosaic of the terraces rising toward the east is criss-crossed by the Danube's left bank tributaries. The areas lying to the south and south-west are characterised by lower-lying terraces covered with wind-blown sand (Kiskunság and Pilis-Alpár sand dunes). The area lies at the interface of the continental, the sub-Mediterranean and the Atlantic climate zones. In terms of vegetation, it can be assigned to the Pannonian forested steppe region. ${ }^{9}$

Dissected by the Danube, the palaeohydrography of the alluvial fan of the Pest Plain differed substantially from the modern one. The river's alluvial fan in the Pest area suggests that the Danube's course gradually changed during the Pleistocene and the Early Holocene, and that it attained its current channel with a $90^{\circ}$ westward rotation. Concurrently with the gradual shift in the river's course and the accumulation of the river terraces, the area was criss-crossed by countless spill streams and side-branches. Dividing into several branches, the river moulded the environment unhindered until the large-scale regulations. The river frequently shifted its course before the $19^{\text {th }}-20^{\text {th }}$ century regulation: meander loops appeared and disappeared, bars were formed and eroded, and the side-branches too changed their course, with new ones evolving and earlier ones partially infilling. Palaeoenvironmental and ecological studies on the Bronze Age landscape are only partially available. ${ }^{10}$

${ }^{4}$ E.g. NovÁKI 1952; BÁNDI 1960; KovÁcs 1963; F. PETRES -BÁNDI 1969; BóNA 1975; ENDRỎDI-Feld 1980; MiKLós 1982; KoVÁCS 1982; BóNA-NovÁKi 1982; PorosZLAI 1988; G. SZÉNÁSZKY 1977; Poroszlai 1991a; Poroszlai 1992a; Poroszlai 1992b; PoROSZLAI 1992c;VICZE 1992; ENDRŌDI-GYULAI 1999; POROSZLAI 19992000; Poroszlai 2000; Miklós 2007a; VÁcZi-StibránYi 2008; P. FisCHL-Guba 2010. For comprehensive summaries, see VICZE 2000; Poroszlai 2003a; HorvÁth 2004a; HoRVÁth 2004b; EarLEKRISTIANSEN 2010; REMÉNYI in press; SZEVERÉNYI-KULCSÁR 2012 with further literature.
${ }^{5}$ PoroszlaI-Vicze 2000; PoroszLaI-Vicze 2005; EARLEKRISTIANSEN 2010

${ }^{6}$ VicZe-EARLe-Artursson 2005; VicZe-CZAJLIK-TímÁR 2005; SÜMEGI-BODOR 2005; EARLE-KolB 2010; EARLE-KRISTIANSEN 2010; EARLE et al. 2011.

${ }^{7}$ PéCSI 1959, 135-142; CZAGánYI 1995, 16-34; CZAGánYI 2000, 21-26; KulCSÁR 2011; SZEVERÉNYI-KuLCSÁR 2012, 316-330.

${ }^{8}$ PÉCSI 1959; SOMOGYI 2007, 32-33, Table 1.

${ }^{9}$ SÜMEGI-Bodor 2000, Figs 3-4.

${ }^{10} \mathrm{Cp}$. KulCSÁR 2011, 179-184, with further references. 


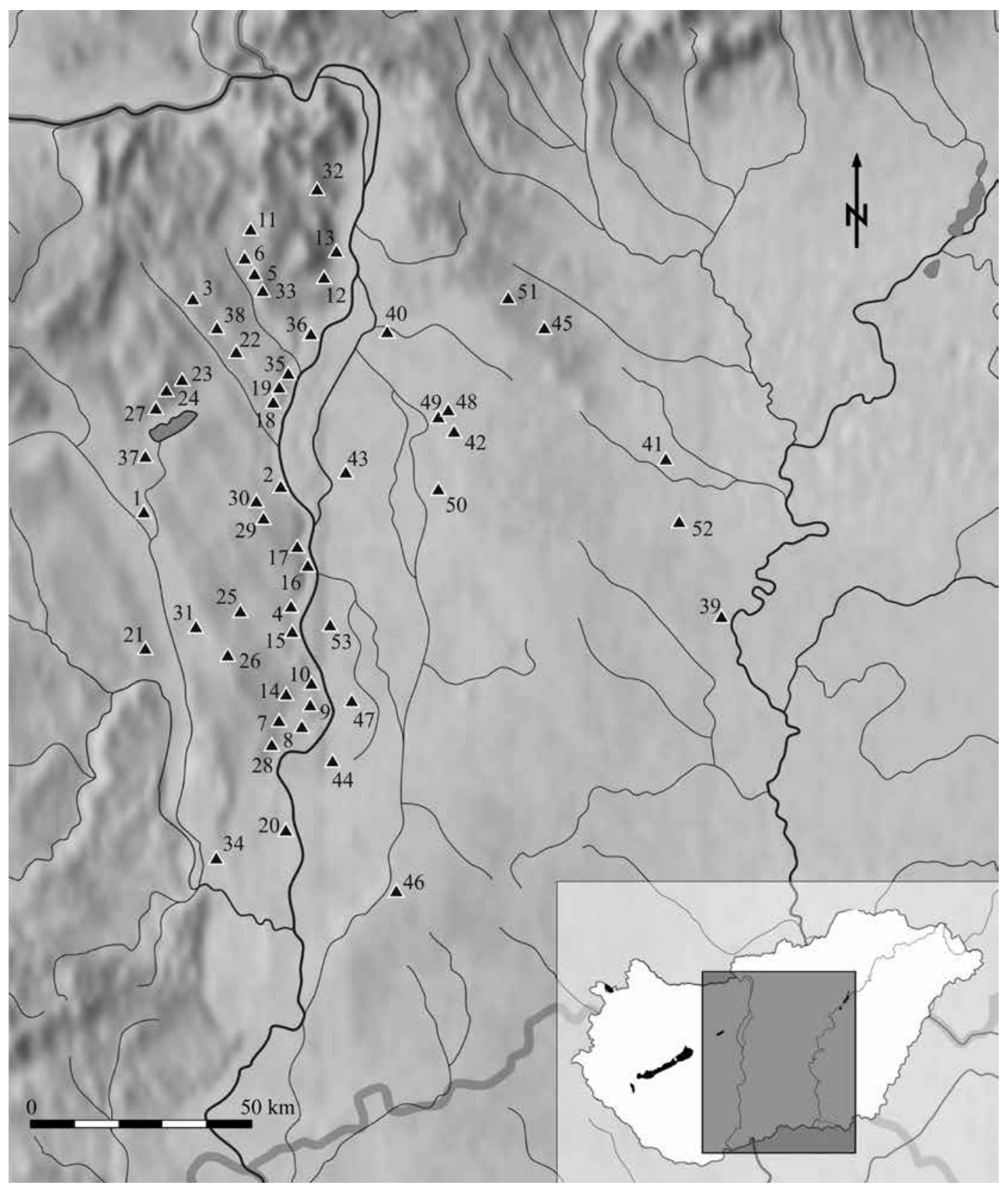

Fig. 1. Middle Bronze Age tells and fortified settlements in Central Hungary (after SzEveréNYI-Kulcsár 2012, Fig. 1) 1: Aba-Belsőbáránd, Bolondvár; 2: Adony-Szentmihály-puszta, Bolondvár; 3: Alcsútdoboz-Göböljárás-Pogányvár; 4: Baracs-Bottyánsánc (today: Dunaföldvár-Macskalyuk), 5: Biatorbágy-Öreg-hegy; 6: Biatorbágy-Pap-réti-dülő; 7: Bölcske-Bolondvár; 8: Bölcske-Hadai-hegy 1; 9: Bölcske-Hadai-hegy 2; 10: Bölcske-Vörösgyír/Vörösgyürü; 11: Budajenő-Hegyi szántók; 12: Budaörs-Kamaraerdő, 13: Budapest-Várhegy; 14: Dunaföldvár-Gyürüstábla; 15: Dunaföldvár-Kálvária (or Öreghegy); 16: Dunaújváros-Kozider-padlás and Kozider-asztal; 17: Dunaújváros-Rácdomb; 18: Ercsi-Bolondvár (today: Beloiannisz-Bolondvár); 19: Ercsi-Holdhegy; 20: Gerjen-Váradpuszta; 21: Igar-Vámpuszta-Galástya, Bolondvár; 22: Kajászó-Várdomb; 23: Lovasberény-Mihályvár; 24: Lovasberény-Szűzvár Szöszvár); 25: Mezőfalva-Bolondvár; 26: Nagykarácsony-Diófás-dűlő; 27: Pákozd-Pákozdvár; 28: Paks/Dunakömlőd-Bottyánsánc (Lussonium);

29: Perkáta-Faluhelyi-dűlő 2; 30: Perkáta-Forrás-dűlő; 31: Sárbogárd-Cifrabolondvár; 32: Solymár-Várhegy (Mátyás-domb); 33: SóskútKálvária-hegy/Barátház; 34: Szedres-Horgász Tanya; 35: Százhalombatta-Dunafüred; 36: Százhalombatta-Földvár (Téglagyár); 37: Székesfehérvár-Börgöndpuszta-Lászlóhegy; 38: Vál-Pogányvár; 39: (Tisza)Alpár-Várdomb; 40: Budapest, Soroksár-Várhegy; 41: CeglédÖregszőlők/Öreghegy; 42: Dabas-Dabasi szőlők; 43: Dömsöd-Leányvár/Tekerős-patak; 44: Dunapataj-Alsószentkirály-Várhegy; 45: Gomba-Várhegy; 46: Hajós-Hildpuszta; 47: Harta-Bojár; 48: Kakucs-Balla-domb and Szélmalom-domb; 49: Kakucs-Turján mögötti dülö/ Dunavölgyi föcsatorna dél; 50: Kunpeszér-Birkajárás 2; 51: Mende-Leányvár; 52: Nagykőrös-Földvár (Várhegy); 53: Solt-Tételhegy 
The remnants of an ancestral Danube channel between Ócsa and Inárcs to the south of Budapest appears as Sárvíz [Sár/Mud waters] or nagy Sár folyó [Great Sár/Mud River] in $13^{\text {th }}$ century charters. ${ }^{11}$ Antal Balla's hydrological map from 1793 shows the river with a wide floodplain coursing through a waterlogged area between Budapest-Soroksár and Kalocsa. ${ }^{12}$ The branches of the extensive marshland preserved their freshwater nature for a long time. Fishing and milling places can be identified from the medieval and post-medieval records, and water mills were still active in the region a few generations before the river regulations in the $1920 \mathrm{~s} .{ }^{13}$ The $18^{\text {th }}$ century maps depicted a world of lakes and marshes on the western outskirts of Ócsa, Inárcs, Kakucs and Dabas, between Bugyi, Sári, Gyón, Kunszentmiklós and Dömsöd. Various islets rose above the river at Bugyi-Ürbő for example ${ }^{14}$ and one could still travel from Ürbö to Kalocsa by boat in the late $19^{\text {th }}$ century. ${ }^{15}$ No more than a handful of sand islands were suitable for settlement in a region which could only be approached by boat for the greater part of the year. Medieval documents recount the continuous efforts to create protection against floods and backwater. The problem of drainage was eventually resolved by a network of artificial channels from the 1910s-1920s. The $150 \mathrm{~km}$ long Danube Valley Main Channel was also created at this time.

A waterlogged area dotted with bogs extends along the boundary of the Danubian plainland and the sand dunes of the Danube-Tisza interfluve. The Ócsa peat-bog is the northernmost bog in this bog sequence. The bogs changed dynamically through the ages: at times, they were deep lakes with crystal clear waters, at times they became infilled and their surface was covered with aquatic plants. The palaeoenvironmental investigation of the Ócsa peat bog at Selyemrét indicated a gradual decrease in the surrounding woodland between the Late Neolithic and the Early Bronze Age accompanied by soil erosion, as a result of which the inflow of humus into the Ócsa sediment catchment intensified and eventually led to its infilling. ${ }^{16}$

\section{THE MIDDLE BRONZE AGE SETTLEMENT NETWORK ON THE LEFT DANUBE BANK: THE KAKUCS AREA}

It is clear from the above broad geographic description that there was another channel that gradually succumbed to eutrophication some 50-60 km from the Csepel Island-Ráckeve/Soroksár Danube main channel which undoubtedly determined the area's environmental potentials. Although the area has not been systematically surveyed, the currently available information seems sufficient for a broad reconstruction of the one-time landscape exploitation.

The area was increasingly intensively settled during the course of the Bronze Age. ${ }^{17}$ In this context, the area along the left Danube bank down to the Kakucs area, lying in close proximity to the eponymous site at Újhartyán-Vatya, is very instructive. Following a scanty occupation marked by a few smaller sites at the onset of the Early Bronze Age, the number of sites and associated cemeteries grew dynamically from the late Nagyrév/early Vatya period onward. ${ }^{18}$ Despite the uncertainties in the relative chronology of the known Middle Bronze Age sites (mostly due to the lack of excavation on these sites), the increase in the number of sites is in itself a reflection of a population growth and increasing landscape exploitation. The left bank of the Danube became one of the period's most intensively settled regions during the Middle Bronze Age 1-3.

For a very long time, mostly cemeteries were known from the geographic centre of the Vatya heartland, i.e. the region extending south of Budapest along the Danube. The culture's eponymous site at Újhartyán-Vatyapuszta $^{19}$ lies in this area. There has been a welcome increase in the number of Middle Bronze Age sites because several new settlements and burial grounds were discovered during the past decades. ${ }^{20}$ The central hillforts fortified by enclosures, such as the ones at Soroksár-Várhegy ${ }^{21}$ and Dömsöd-Leányvár, ${ }^{22}$ and the associated open settlements formed the backbone of the Vatya settlement network which, on the testimony of the field survey data, also com-

\footnotetext{
${ }^{11}$ CZAGányi 1995, 19; CZAGÁNyi 2000.

${ }^{12}$ Keleti-Lakatos-MakKai 1965.

${ }^{13}$ CZAGÁNYi 1995, 16-34; CZAGÁNYi 2000, 21-26.

${ }^{14}$ BÓNA 1957, 155-157.

${ }^{15}$ CZAGánYi 2000, 21.

${ }^{16}$ VERES 2007; VERES-SÜMEGI-TÖRŐCSIK 2011.

${ }^{17}$ A similar demographic growth has been posited for the regions west of the Danube, KALICZ-SCHREIBER 1995b.
}

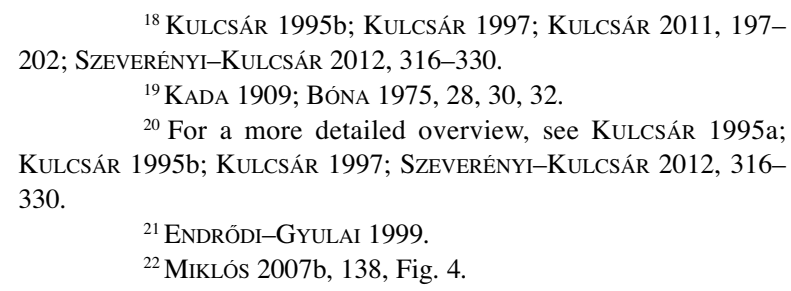

${ }^{18}$ KulCSÁR 1995b; KulCSÁR 1997; KulCSÁR 2011, 197 202; SZEVERÉNYI-KuLCSÁR 2012, 316-330.

${ }^{19}$ KADA 1909; BÓNA 1975, 28, 30, 32.

${ }^{20}$ For a more detailed overview, see Kulcsár 1995a; KulCSÁr 1995b; KulCSÁR 1997; SZEVERÉNYI-KulCSÁR 2012, 316330.

${ }^{21}$ ENDRŐDI-GYULAI 1999.

${ }^{22}$ Miklós 2007b, 138, Fig. 4. 

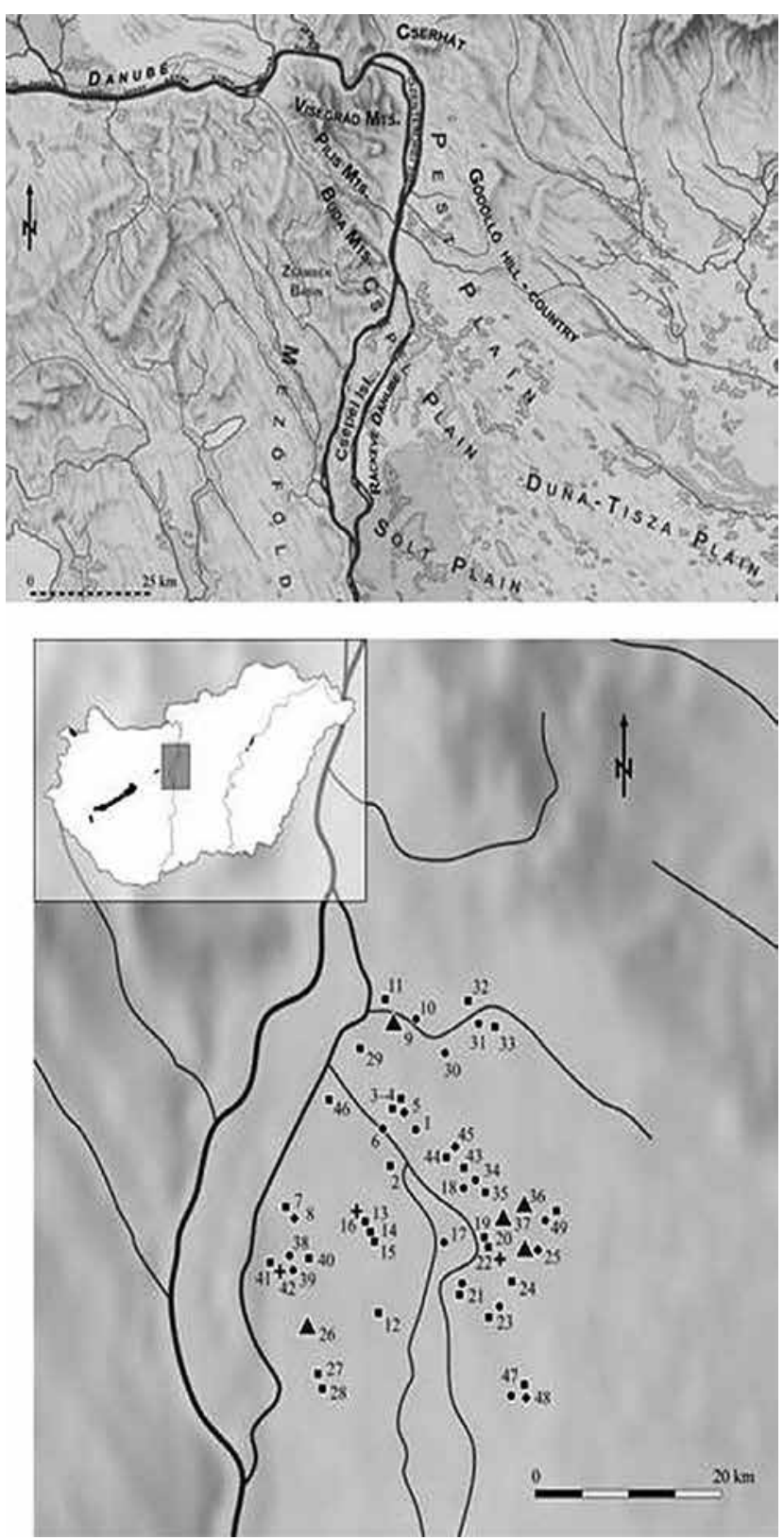

Fig. 2. Geographical map of the Budapest area and the Middle Bronze Age sites in the Kakucs microregion. Triangles: tells and fortified settlements; circles: open settlements; squares: graves and cemeteries; crosses: stray finds of uncertain character; rhombi: bronze hoards (after SZEVERÉNYI-KuLCSÁR 2012, Fig. 27)

1: Alsónémedi-Kóhalom-Templomhegy; 2: Alsónémedi/Bugyi-Pusztatemplom-dűlö; 3: Alsónémedi, "500-700 m from the new village"; 4: Alsónémedi; 5: Alsónémedi; 6: Alsónémedi-Duna-Tisza Canal, 12360-80 m; 7: Áporka; 8: Áporka-Pusztaszentkirály; 9: Budapest, SoroksárVárhegy; 10: Budapest, Soroksár-Nagy-rét, Site 1; 11: Budapest-Soroksári út; 12: Bugyi-Ürbőpuszta; 13: Bugyi-Malomkert; 14: Bugyi, formerly Vargha Emil's estate; 15: Bugyi, east of the village; 16: Bugyi; 17: Dabas-Sári-Fehérháti földek; 18: Dabas-Sári/Ócsa-Nádi-dülő,

Földvár-sziget; 19: Dabas-Sári; 20: between Dabas-Sári and Bugyi; 21: Dabas, Site 83, Belsőmántelek (Kis-földek); 22: Dabas (former Alsódabas); 23: Dabas-Gyón-Nagypaphegy; 24: Dabas-Gyón; 25: Dabas-Dabasi szőlők; 26: Dömsöd-Leányvár/Tekerös patak; 27: Dömsöd, east of the village; 28: Dömsöd-Fazekas I.'s estate; 29: Dunaharaszti-Bajcsy-Zsilinszky u. 104./Mező Imre utca/Deák F. u.; 30: Gyál, Site 5; 31: Gyál, Site 7; 32: Gyál-Majakovszkij (Puskás) utca 37, Bitó-hegy; 33: Gyál-Löbpuszta; 34: Inárcs-Cibak-Kaszás-tanya; 35: Inárcs-Csemetekert; 36: Kakucs-Balla-domb and Szélmalom-domb; 37: Kakucs-Turján mögötti dülö/Dunavölgyi föcsatorna dél; 38: Kiskunlacháza-Kavicsbánya; 39:

Kiskunlacháza; 40: Kiskunlacháza-Bankházapuszta, between Pereg and Bugyi; 41: Kiskunlacháza-Pereg-Virágos; 42: Kiskunlacháza; 43: ÓcsaÖregszőlők/Öreghegyi-dűlő (former Üveghegyi-dűlő); 44: Ócsa-Bajcsy-Zsilinszky u. 49; 45: Ócsa-Klapka u. 6; 46: Taksony-Dunakisvarsány; 47: Tatárszentgyörgy-Sarlósárpuszta; 48: Tatárszentgyörgy; 49: Újhartyán (today Újlengyel)-Vatya-puszta 
prised smaller villages and farmsteads such as the one recorded at Gyál ${ }^{23}$ (Fig. 2). In addition to the settlements, a series of larger and smaller cemeteries are also known. ${ }^{24}$

The Kakucs area is one of the more intensely investigated micro-regions. Although the area has not been systematically surveyed, Bronze Age finds have been continuously found and reported from this area since the 1900s. The currently known two largest, most extensive sites in the area are Kakucs-Balla domb and Kakucs-Szélmalom domb. Several smaller settlements, such as the one at Újhartyán-Földek, have been identified along the one-time river channel within a $0.1-1 \mathrm{~km}$ radius of the central settlement extending over two (or perhaps even three) elevations. Larger settlements, similarly protected by enclosures, are known within a $10 \mathrm{~km}$ radius of the KakucsBalla domb site: the settlement at Kakucs-Turján mögötti-dülö/Dunavölgyi föcsatorna dél lies some $3 \mathrm{~km}$ to the west, ${ }^{25}$ Dabas-Dabasi Szőlök $6 \mathrm{~km}$ to the south ${ }^{26}$ and the cemetery and settlement of the eponymous site at Újhartyán-Vatya-puszta can be found to the east. ${ }^{27} \mathrm{~A}$ chain of settlements and burial grounds can be found towards the north-east, marked by the sites at Inárcs, Ócsa, Dabas-Belső Mántelek, Dabas-Sári, Bugyi and Alsónémedi (Fig. 2). ${ }^{28}$

\section{KAKUCS-BALLA-DOMB: THE BRONZE AGE SETTLEMENT}

The remains of an extensive settlement extend across two large hills rising above the former Tó-környék marshland on the south-western outskirts of Kakucs. The two hills are located on the left side of the Danube Valley Main Channel draining the area. The smaller hill is known as Balla-domb, the larger one to its south-west is called Szélmalom-domb (Fig. 3). The Szélmalom-domb is marked on the maps of the First and the Second Ordnance Survey conducted in 1780-1784 and 1829-1867, respectively (Fig. 3.1).

We collected various finds indicating occupation during the Bronze Age on the Szélmalom-domb, currently under cultivation, during the field survey conducted in 1991. The same year, we were informed by L. Czagányi that various prehistoric artefacts had regularly come to light during construction and gardening work on the steep hillside between Fö út and Malomkert út. ${ }^{29}$ In 1992-93, we therefore conducted a rescue excavation in an area known as the Balla plot that would soon be built up, but was still undisturbed at the time. The site was named Balla-domb after Ferenc Balla $(\dagger)$, the former director of the elementary school, who owned the plot on the hilltop. Rising some 5-6 $\mathrm{m}$ above the surrounding area, the built-in, roughly oval hill has a diameter of $c a .125 \mathrm{~m}$. Adjoining it from the south-west is the Szélmalom-domb, a larger hill measuring $250 \mathrm{~m}$ by $250 \mathrm{~m}$ that gradually spreads out towards the south-west and grades into the lower-lying plain once covered with water. The two hills were probably once part of the same settlement. Judging from the surface finds, a third hill, the so-called Liebner-domb on the other side of Fö út, was probably also part of the same settlement centre. Traces of other settlements were identified on the opposite side of the Danube Valley Main Channel, on the outskirts of Újhartyán in an area known as Külső földek during the field survey conducted in 2010. ${ }^{30}$

All traces of an earthen rampart and ditch around and between the Szélmalom-domb and the Balla-domb have disappeared. However, it must be noted that two modern streets (Fö út and Malomkert út) run in a depression between and around the two hills. These may have been natural depressions, but they may equally indicate the location of the one-time enclosures protecting the settlement.

\section{The settlement features and their chronology}

In 1992-93, we opened two trenches in the relatively undisturbed and unbuilt areas: one in the hill's central, highest area (Trench A, $10 \mathrm{~m}$ by $10 \mathrm{~m}$ ) and another one on the north-eastern slope (Trench B, $4 \mathrm{~m}$ by $5 \mathrm{~m}$ ) (Fig.

\footnotetext{
${ }^{23}$ SZEVERÉNYI in press.

${ }^{24}$ E. g. BóNa 1975, 31-78; SZATHMÁRI 1996.

${ }^{25}$ CZajliK et al. 2008, 121, Fig. 1; MikLós 2008, 147, Fig.

3.

${ }^{26}$ CZAJLIK-BÖDŐCs-RupniK 2010, 86, Fig. 4. 2; Miklós 2010, 115, Fig. 6.
}

${ }^{27}$ KADA 1909.

${ }^{28}$ With further references see SZEVERÉNYI-KULCSÁR 2012,

Tab. 3.

${ }^{29}$ For a summary of previous research at the site see KulCSÁr 1995a; KulCSÁr 1995b; KulCSÁR 1997; KulCSÁR 2008.

${ }^{30}$ Field survey conducted with Vajk Szeverényi in 2010. 


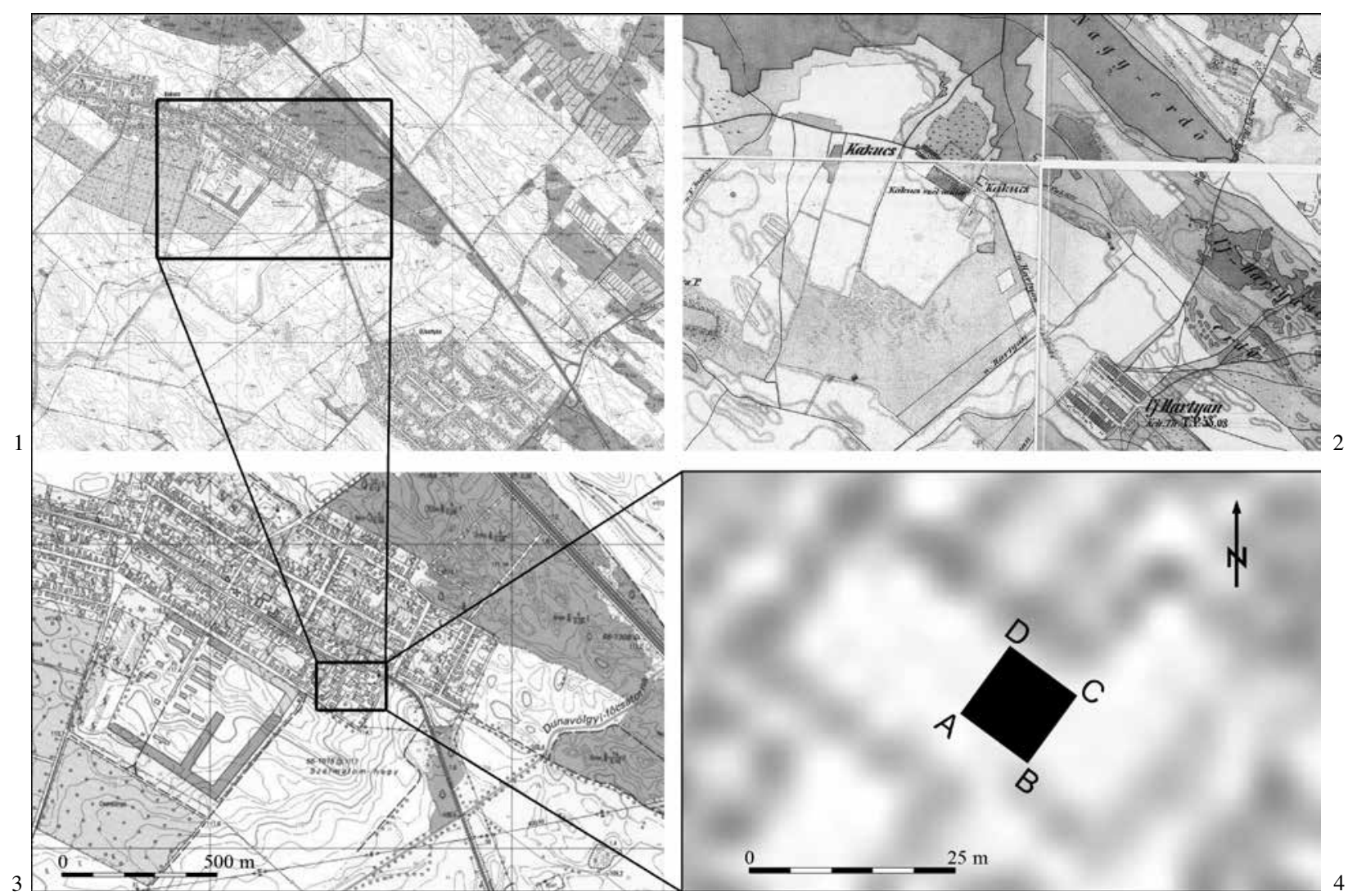

Fig. 3. 1: Kakucs on the maps of the First and the Second Ordnance Survey conducted in 1780-1784 and 1829-1867; 2: location of the sites at Kakucs-Balla-domb and Szélmalom-domb; 3: Kakucs-Balla-domb; 4: Kakucs-Balla-domb, Trench A

3.3-4). ${ }^{31}$ In 2010, we had the opportunity to submit ten samples for radiocarbon measurements (Table 1). ${ }^{32}$ We selected animal and human bone samples recovered from Trench A and thus the dates obtained from the measurements will be included in the description of the excavated settlement section. We strove to select samples from well-definable features, such as burials, animal bones embedded in wall remains and securely identifiable pits. Even so, knowing the nature of stratified tell settlements, there was a fair risk of mixing between the finds, as will be shown below.

We distinguished four occupation levels characterised by house plans with a plastered floor in the $1.5 \mathrm{~m}$ thick layer sequence between the earliest pits dug into the prehistoric humus level and the sub-humus/uppermost mixed deposit overlying the settlement (Fig. 4). The settlement was occupied from the late Nagyrév/early Vatya to the Vatya III/Vatya-Koszider period. Most Vatya settlements are characterised by an abundance of pits, perhaps indicating the shift of various activity areas within the settlement. ${ }^{33}$ The presence of so many pits usually makes the exact separation of occupation levels somewhat difficult, and the Kakucs site was no exception. We divided Trench A into $2 \mathrm{~m}$ by $2 \mathrm{~m}$ squares and then proceeded to excavate and record the various features according to the one-time occupation levels.

The 40-50 cm thick strongly disturbed topsoil mixed with modern debris was removed mechanically. The loose earth of the underlying 30-35 cm thick sub-humus layer was mixed with the debris of the uppermost deposit of the Bronze Age settlement, and contained a rich assortment of Bronze Age, medieval and modern artefacts. This was

${ }^{31}$ The preliminary assessment of the finds was part of an MA thesis, KULCSÁR 1995b.

${ }^{32}$ Samples for radiocarbon measurements were collected as part of M. Jaeger's PhD thesis. The samples were submitted to the Radiocarbon Laboratory in Poznań, through a grant from Poland.
${ }^{33}$ Cp. Százhalombatta-Földvár: PoroszLai 2000; PoroszLAI 2003a; VICZE 2004; VICZE 2013.

Acta Archaeologica Academiae Scientiarum Hungaricae 64, 2013 
Table 1. Radiocarbon dates from Kakucs-Balla-domb. The dates were calibrated using the OxCal v4.1.7 programme and the IntCal09 calibration curve (https://c14.arch.ox.ac.uk/oxcal/OxCal.html)

\begin{tabular}{|c|c|c|c|c|c|c|c|}
\hline Lab. No. & Date BP & Cal BC & & $\begin{array}{l}\text { Sample } \\
\text { material }\end{array}$ & Level & Provenance & $\begin{array}{c}\text { Relative } \\
\text { chronology }\end{array}$ \\
\hline Poz-36175 & $3230 \pm 35$ & $\begin{array}{l}1526-1449(68.2 \%) \\
1608-1430(95.4 \%)\end{array}$ & $4.1 \% \mathrm{~N} 7.9 \% \mathrm{C}$ & Human bone & Top & $\begin{array}{l}\text { A/Feature } 3 \\
\text { (Grave) }\end{array}$ & $\begin{array}{l}\text { Vatya-Koszider or } \\
\text { Tumulus Grave }\end{array}$ \\
\hline Poz-36177 & $3315 \pm 30$ & $\begin{array}{l}1627-1532(68.2 \%) \\
1681-1521(95.4 \%)\end{array}$ & $3.8 \% \mathrm{~N} 9.7 \% \mathrm{C}$ & Animal bone & 1 & $\mathrm{~A} / 3 / 2$ & $\begin{array}{l}\text { Vatya III- } \\
\text { Vatya-Koszider }\end{array}$ \\
\hline Poz-36176 & $3510 \pm 35$ & $\begin{array}{l}1889-1772(68.2 \%) \\
1928-1744(95.4 \%)\end{array}$ & $3.2 \% \mathrm{~N} 8.4 \% \mathrm{C}$ & Animal bone & 1 & A/Wall 1, Wall 2 & $\begin{array}{l}\text { Vatya III- } \\
\text { Vatya-Koszider }\end{array}$ \\
\hline Poz-36178 & $3550 \pm 35$ & $\begin{array}{l}1947-1782(68.2 \%) \\
2012-1771(95.4 \%)\end{array}$ & $1.5 \% \mathrm{~N} 4.2 \% \mathrm{C}$ & Animal bone & 2 & $\mathrm{~A} / 5 / 3-4$ & Vatya II-III \\
\hline Poz-36202 & $3590 \pm 35$ & $\begin{array}{l}2010-1896(68.2 \%) \\
2036-1783(95.4 \%)\end{array}$ & $3.2 \% \mathrm{~N} 7.7 \% \mathrm{C}$ & Animal bone & 2 & $\mathrm{~A} / 3-5 / 1-3$ & Vatya II-III \\
\hline Poz-36203 & $3605 \pm 35$ & $\begin{array}{l}2022-1919(68.2 \%) \\
2120-1882(95.4 \%)\end{array}$ & $3.1 \% \mathrm{~N} 7.6 \% \mathrm{C}$ & Animal bone & 3 & $\mathrm{~A} / 3-5 / 1-3$ & Vatya II-III \\
\hline Poz-36207 & $3530 \pm 30$ & $\begin{array}{l}1918-1777(68.2 \%) \\
1943-1757(95.4 \%)\end{array}$ & $4.2 \% \mathrm{~N} 9.2 \% \mathrm{C}$ & Animal bone & 2 & A/Feature 4-5 & Vatya II-III \\
\hline Poz-36204 & $3605 \pm 35$ & $\begin{array}{l}2022-1919(68.2 \%) \\
2120-1882(95.4 \%)\end{array}$ & $3.0 \% \mathrm{~N} 7.6 \% \mathrm{C}$ & Animal bone & 3 & A/Pit 9 & Vatya I-II \\
\hline Poz-36206 & $3470 \pm 30$ & $\begin{array}{l}1877-1744(68.2 \%) \\
1884-1694(95.4 \%)\end{array}$ & $4.4 \% \mathrm{~N} 10.5 \% \mathrm{C}$ & Animal bone & $4 / 3$ & A/Pit 15 & Vatya I-II \\
\hline Poz-36205 & $3565 \pm 30$ & $\begin{array}{l}1956-1881(68.2 \%) \\
2021-1777(95.4 \%)\end{array}$ & $4.1 \% \mathrm{~N} 10.2 \% \mathrm{C}$ & Animal bone & $\begin{array}{l}\text { Prehistoric } \\
\text { humus }\end{array}$ & A/Pit 14 & Vatya I \\
\hline
\end{tabular}

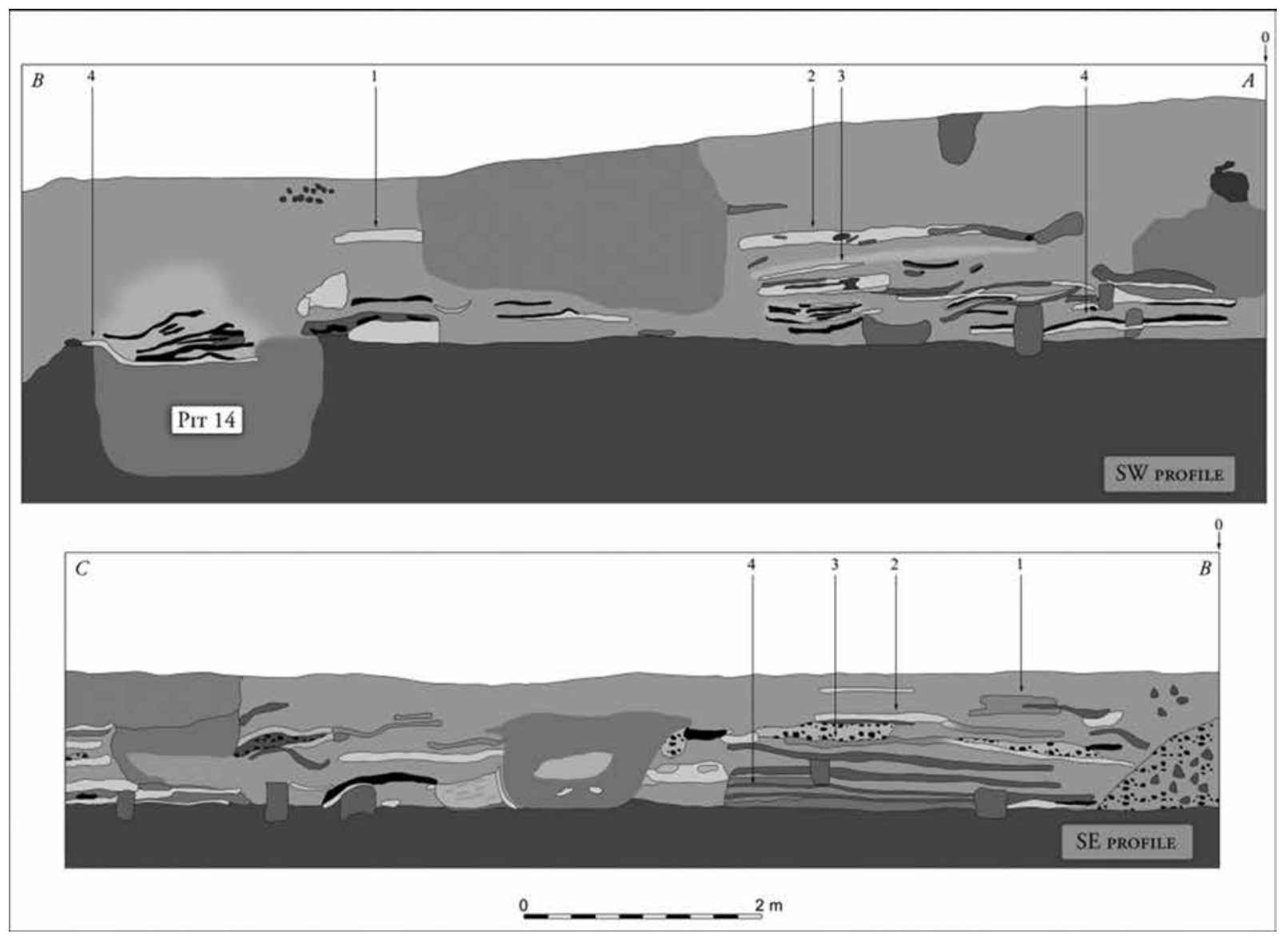

Fig. 4. Kakucs-Balla-domb. The SW and SE profiles of Trench A with four levels 

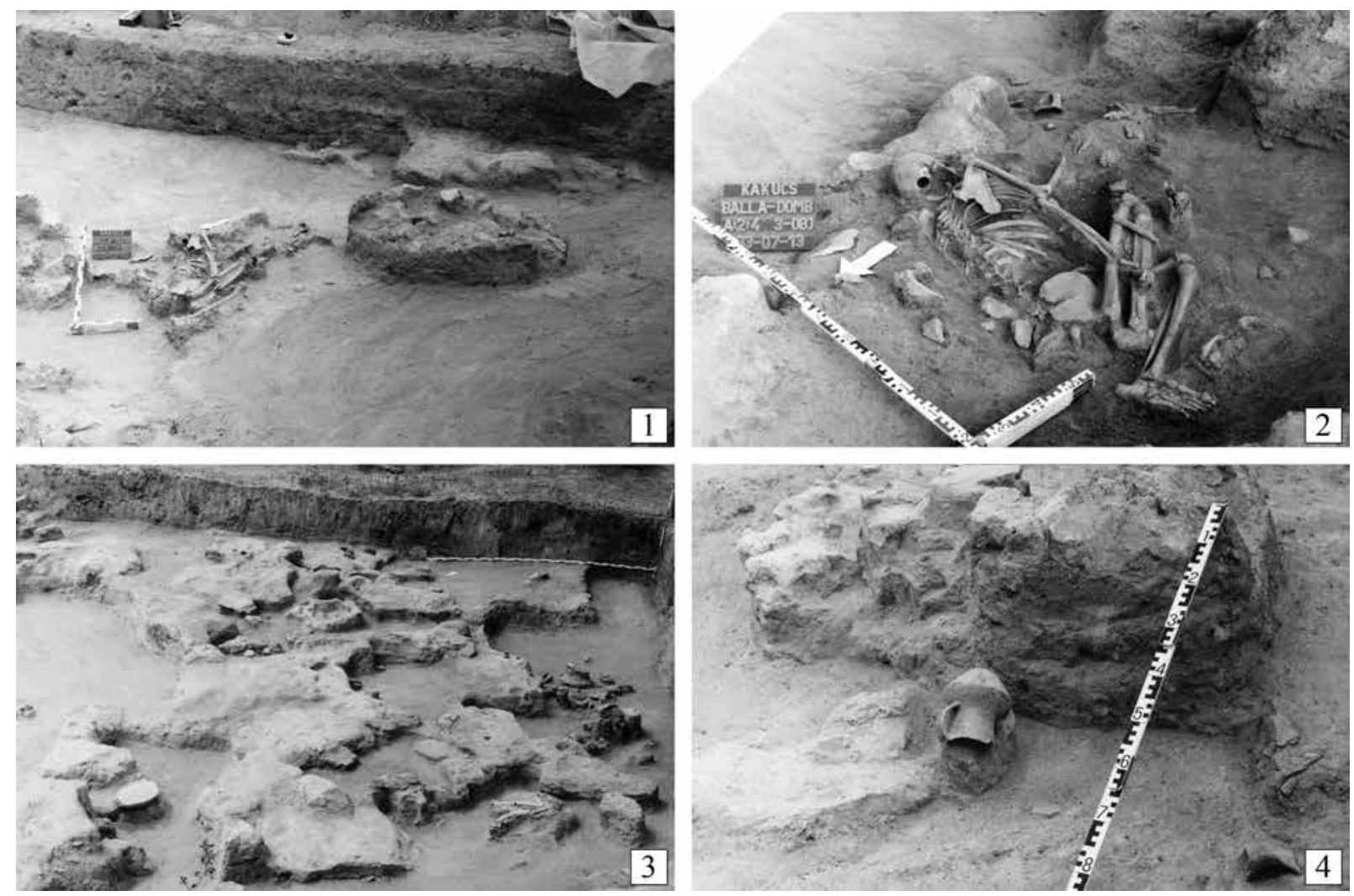

Fig. 5. Kakucs-Balla-domb. 1-2: Feature A/3, Grave; 3-4: Level 1
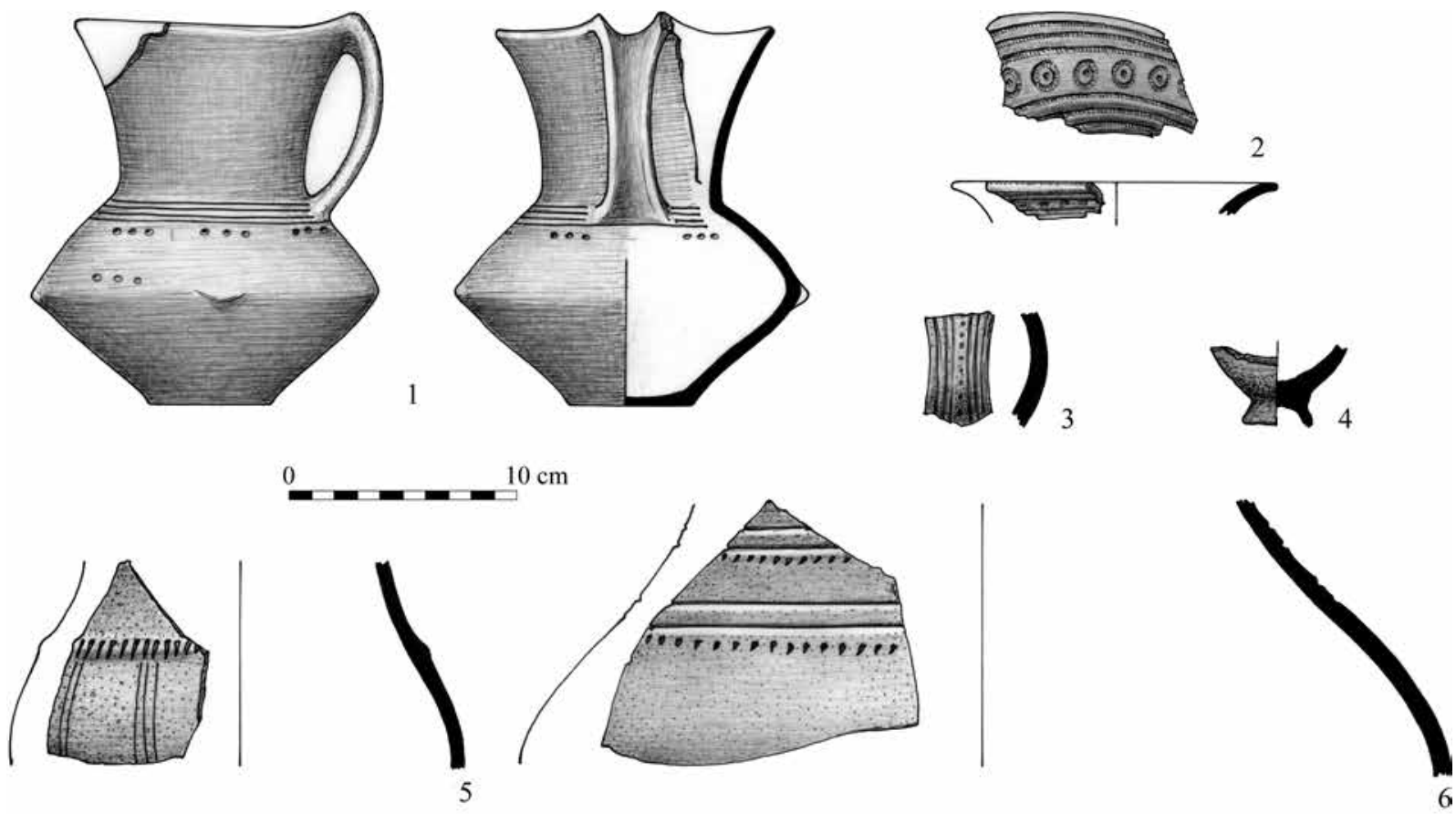

Fig. 6. Kakucs-Balla-domb. 1-6: Selection of finds from the area of Feature A/3 

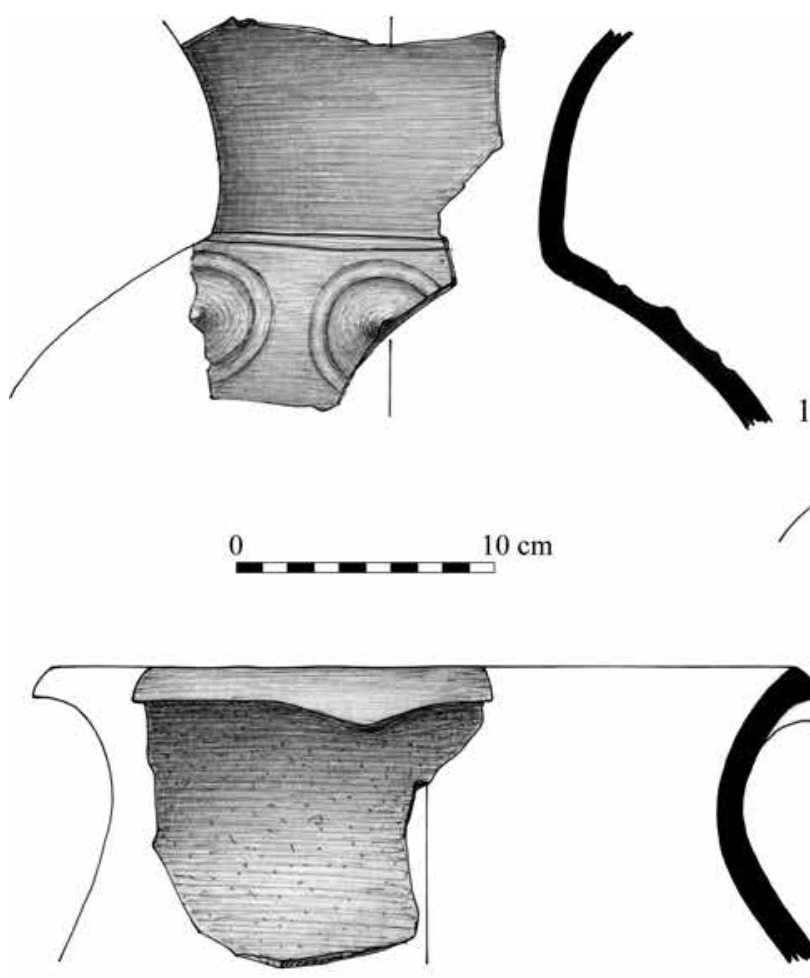

Fig. 7. Kakucs-Balla-domb. 1-5: Selection of finds from Unit A/3/2 of Level 1

followed by the settlement's uppermost deposit, which covered Level 1 of the settlement. The soil marks of several pits indicating the end of the Bronze Age occupation could be noted in this deposit. It was often difficult to precisely observe the outlines of these pits in the greyish, mixed surface of the uppermost deposit. We attempted to distinguish individual pits by carefully proceeding downward. The exact outline of the pits could be recorded in Level 1, where the pits intruded into the plastered floor of the one-time buildings. However, owing to the pits, we were unable to distinguish individual house plans and could only document the fragments of the plastered floors and a few surviving terre pisé walls (Fig. 5). On the testimony of the finds, the uppermost deposit and Level 1 could be assigned to the Vatya III and the Vatya III-Koszider period (Figs 6-8). Samples for radiocarbon dating were submitted from a crouched inhumation burial found in Pit "a", one of the largest pits uncovered in the trench (Feature A/3; Poz-36175; Fig. 5.1-2; Fig. 6, Table 1). ${ }^{34}$ The left-side crouched burial of an 18-20 years old juvenile male was SE-NW oriented and lacked grave goods. ${ }^{35}$ The grave pit was clearly dug into the occupation level and was backfilled with earth mixed with settlement debris. The sample gave a date of 1526-1449 (68.2\%) cal BC (Table 1). Level 1 can be dated to 1627-1532 (68.2\%) cal BC on the testimony of a sample taken from one of the floors (Level 1, Section A/3/2; Poz-36177; Table 1, Fig. 7). Another sample from the same level gave a much earlier date: the sample from the 1-1.5 m long surviving section of a red burnt wall remain yielded a date of 1889-1772 (68.2\%) cal BC (Level 1, Section A/Wall 1-2; Poz-36176; Table 1, Fig. 8).

Moving downward the traces of pits intruding from the overlying level could still be observed in Level 2. Level 2 was closely associated with Level 3 (Fig. 4; Fig. 9). The two buildings with a plastered clay floor uncovered in the two levels were erected in the same spot in both levels, the floor of the buildings was renewed in the same area and the refuse pits too lay in roughly the same area. The ceramic wares from Levels $2-3$ can be predominantly assigned to the Vatya II (-III) period (Figs 11-12). The close association of the two levels is confirmed by the samples from the area of the successively rebuilt houses, which gave dates of 2010-1896 (68.2\%) cal BC (Level 2,

${ }^{34}$ Pit "a" extended down to the lowermost level and cut into the prehistoric humus. We are able to distinguish different phases in its fill.
${ }^{35}$ We wish to thank Éva Susa for the anthropological evaluation. 

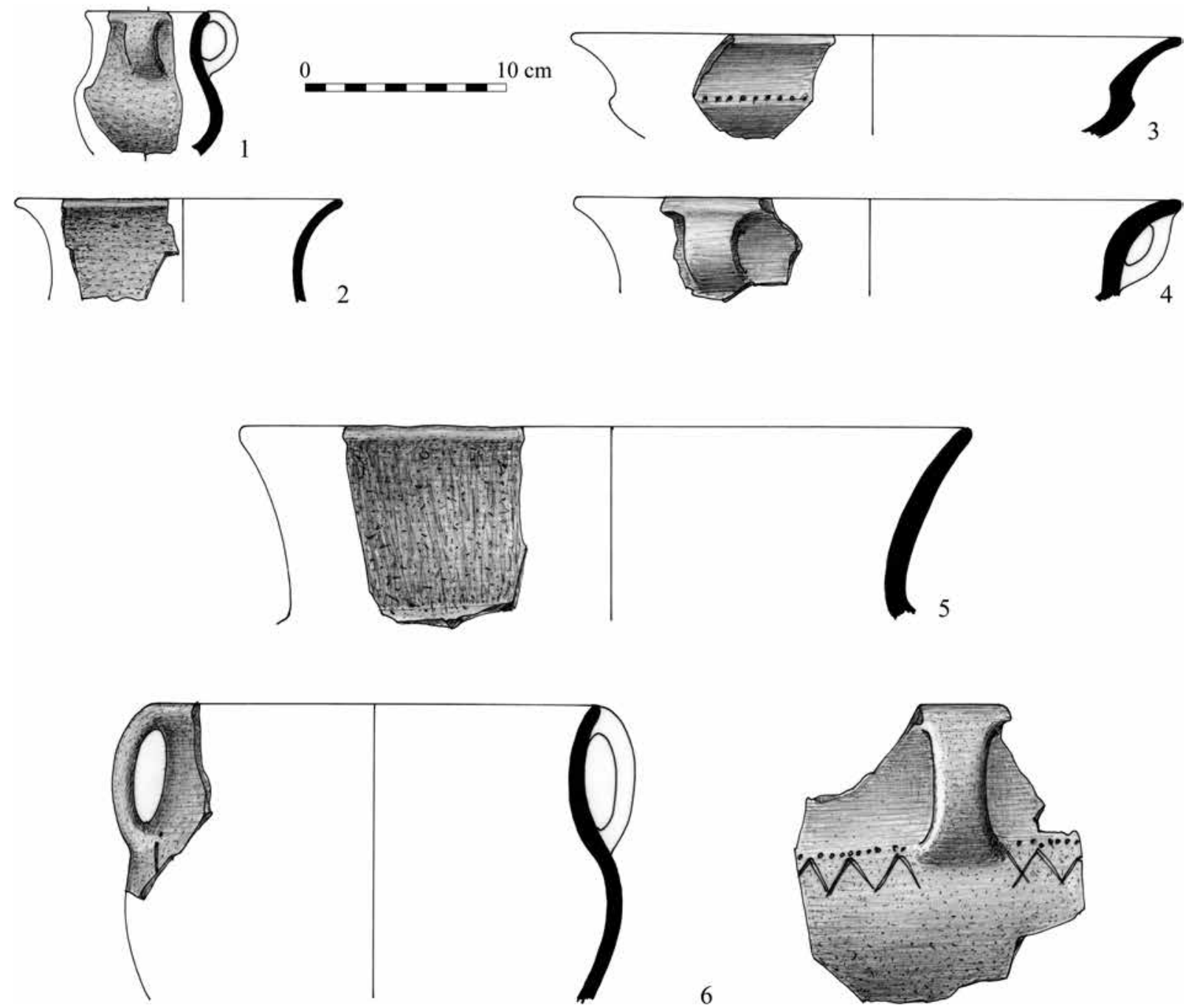

Fig. 8. Kakucs-Balla-domb. 1-6: Selection of finds from Unit A/3-5/1 of Level 1

Section A/3-5/1-3; Poz-36202; Fig. 10) and 2022-1919 (68.2\%) cal BC (Level 3, Section A/3-5/1-3; Poz-36203; Fig. 11) (Table 1). The date of 1947-1782 (68.2\%) cal BC (Level 2, Section A/5/3-4; Poz-36178; Fig. 12) for another contemporaneous house area in Level 2 fits into this sequence (Table 1). Feature 4-5, a pit, could be associated with this level (Fig. 9.3-4). The pit contained a halved, headless cattle body with the limbs placed on top of each other, as well as typical Vatya cups and other pottery sherds (Fig. 13). Samples from the cattle bones yielded a date of 1918-1777 (68.2\%) cal BC (Feature A/4-5; Poz-36207) (Table 1). Pit 9, a beehive shaped pit which reached to the prehistoric humus level (Fig. 16.1), can be linked to the early phase of Level 3, as shown by the presence of both early Vatya and Vatya II/III pottery among its finds (Figs 14-15). The date for this pit, 2022-1919 (68.2\%) cal BC (Pit A/9; Poz-36204), represents an earlier occupation phase (Table 1).

Level 4 was characterised by houses with a plastered clay floor erected directly on the prehistoric humus level (Fig. 4; Fig. 16.2). We found the remnants of clay floors separated by gaps which, however, were not pits, but a "street" littered with debris and refuse. The floors were renewed once or twice with fresh plastering. It is difficult to reconstruct the rhythm of the rebuilding activity after the occupation phase represented by Level 4 because in some areas, the surface was levelled and covered with a 25-30 or even $40 \mathrm{~cm}$ thick mixed, brownish-grey layer, while in others, the use of earlier buildings continued. The dynamic shift in activity areas could be noted in all phases of the settlement's occupation. Pit 15 can be associated with the late phase of Level 4 . The rather late date 

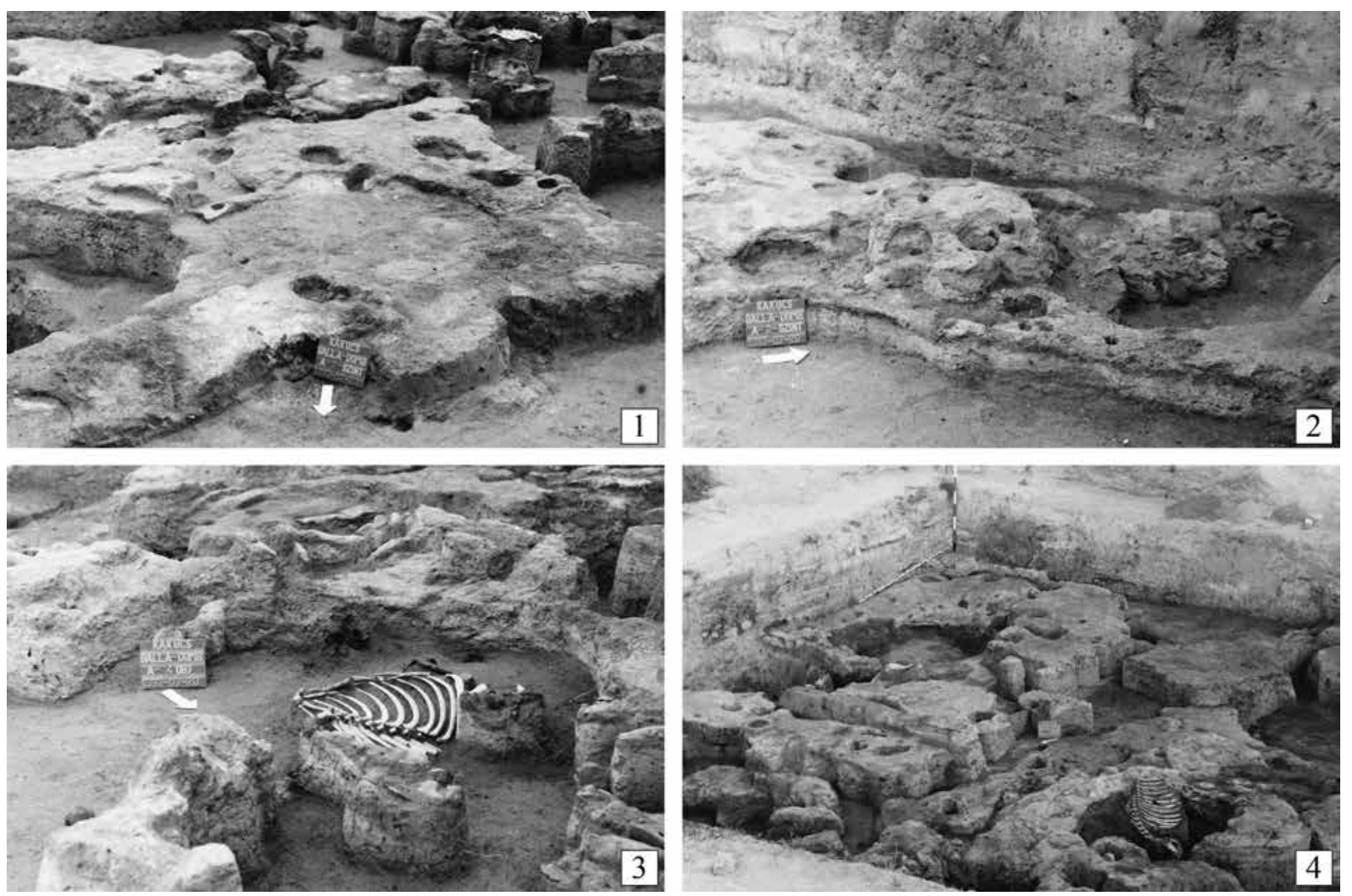

Fig. 9. Kakucs-Balla-domb. 1-2: Level 2; 3: Feature A/4-5; 4: Level 3 with Features A/4-5

obtained for this feature, 1877-1744 (68.2\%) cal BC (Pit A/15; Poz-36206; Table 1, Fig. 17) perhaps indicates that finds from a later period had intruded into Pit 15 from later pits (see Feature A/4-5) either during the excavation or during the settlement's occupation.

The earliest phase of the Kakucs-Balla-domb settlement is indicated by the pits dug into the dark brown prehistoric humus level, which was reached at a depth of $230-240 \mathrm{~cm}$ from the 0 point (Fig. 4; Fig. 16.3). This $70-100 \mathrm{~cm}$ thick prehistoric humus level overlies the hill's geological bedrock. Seventeen pits and several postholes could be identified in the prehistoric humus level. Seven pits represented the settlement's earliest occupation, while the other pits were dug into the humus from a later, higher-lying level. The finds indicate that the artefactual material from the earliest pits and from Level 4 cannot be sharply distinguished because both contain late Nagyrév/ early Vatya and Vatya I ceramics. We decided to date a sample from Pit 14 because it contained very typical early Vatya material (Fig. 4; Fig. 18). Surprisingly enough, the date of 1956-1881 (68.2\%) cal BC (Pit A/14; Poz-36205) was closer to the dates from Levels 2-3 (Table 1).

In sum, the typochronological and stratigraphic evidence shows that the settlement was occupied continuously from the late Nagyrév/early Vatya transition to the Vatya III and Vatya-Koszider period, spanning the period between the turn of the Hungarian Early Bronze Age 3/Middle Bronze Age 1 and the close of the Middle Bronze Age 3 in the relative chronological framework. This corresponds to the RB A1/A2-RB B period. The currently available absolute dates for the Kakucs settlement indicate that the site was occupied between 2022-1919 and 1627-1532 (68.2\%) cal BC, although the date of the burial, 1526-1449 (68.2\%) cal BC, must also be considered (Table 1, Fig. 19). The detailed assessment of the finds and of the settlement layout will no doubt contribute to a finer periodization of the Vatya ceramic style. One point that emerges clearly is that problems caused by the mixing of the finds on a tell settlement can only be prevented by very precise sampling. An explicit correlation between ceramic styles and absolute chronological dates is not possible, in part owing to the continuous changes in the settlement's layout and the lack of burnt destruction levels, and in part to the margin of error of the radiocarbon dates. 

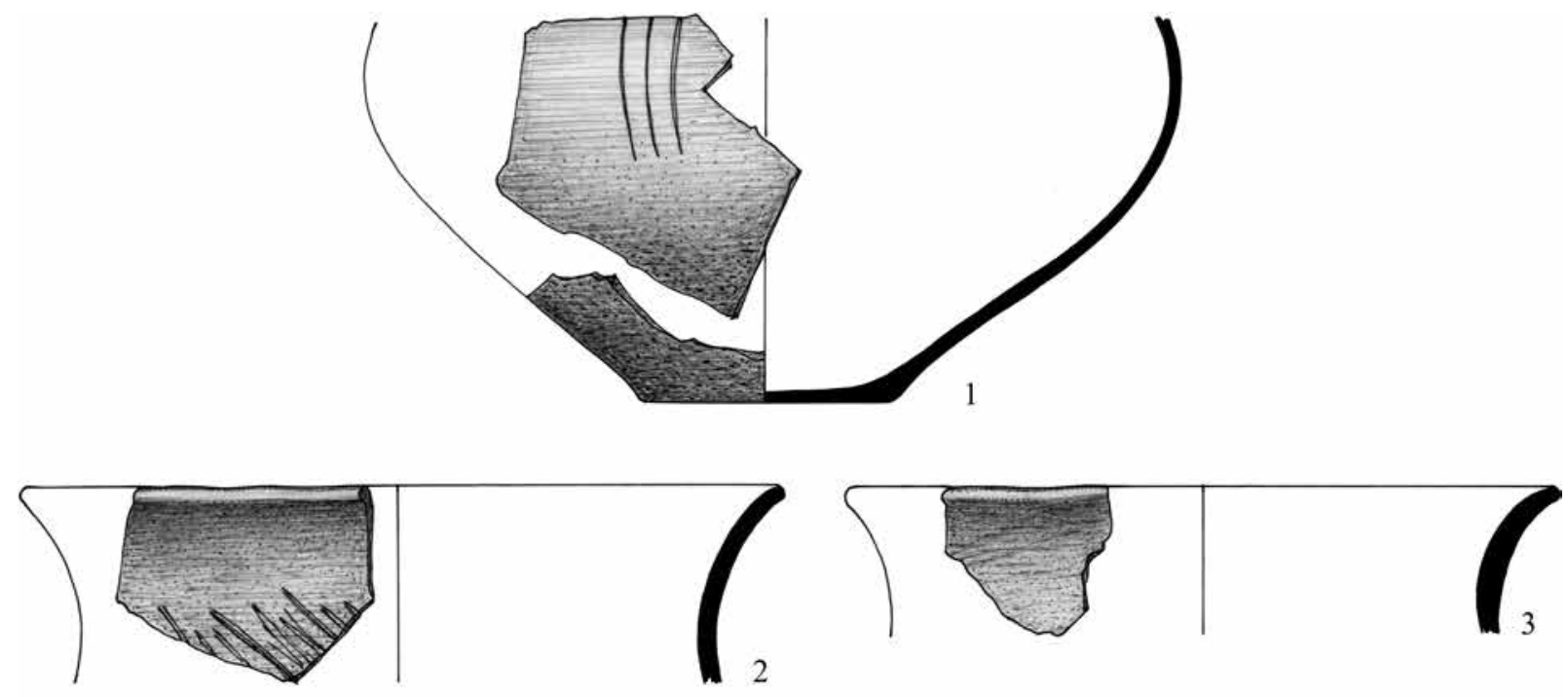

2
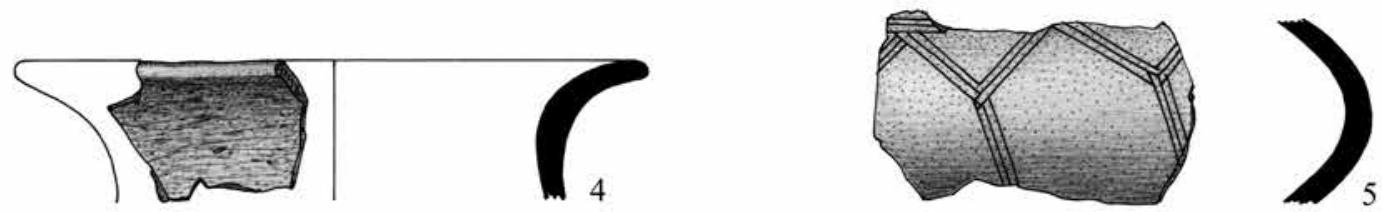

$0 .-10 \mathrm{~cm}$

Fig. 10. Kakucs-Balla-domb. 1: Selection of finds from Unit A/3-5/2-3 of Level 2; 2-5: selection of finds from Unit A/3-5/1-3 of Level 2
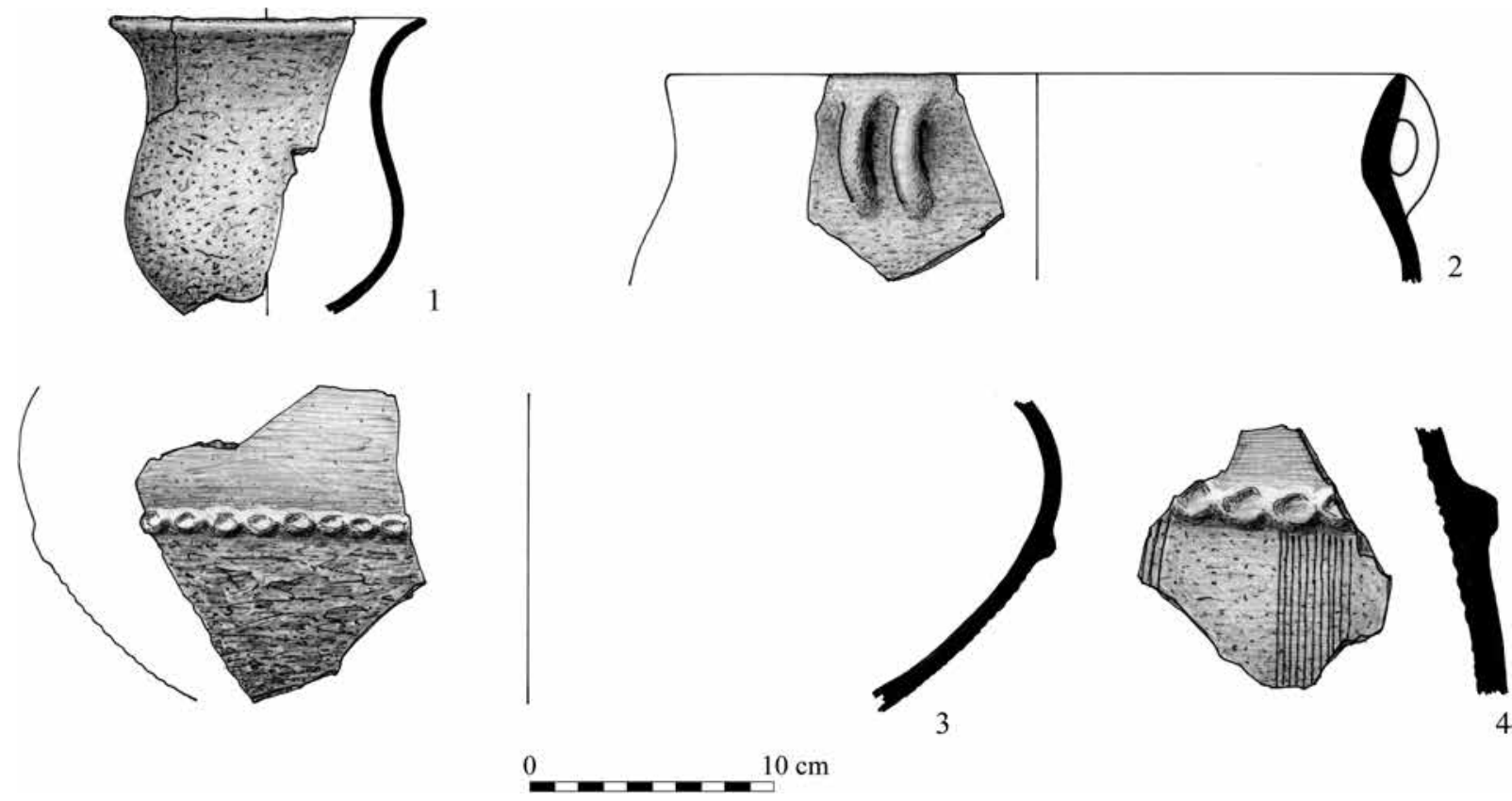

Fig. 11. Kakucs-Balla-domb. 1-4: Selection of finds from Unit A/3-5/1-3 of Level 3 


\section{NOTES ON THE ABSOLUTE CHRONOLOGY OF THE FORTIFIED SETTLEMENTS OF THE VATYA CULTURE}

The wide-ranging issue of the Bronze Age chronology of the Carpathian Basin is a problem that would deserve a separate study. The most important studies seeking to reconcile the chronological schemes constructed before World War 2 and during the later $20^{\text {th }}$ century have been described in detail by W. David. ${ }^{36}$ These schemes were based solely on stratigraphic observations made on settlement and cemetery sites, and on the typology of pottery and metal artefacts, the latter including hoards. ${ }^{37}$ The main reason for this situation is the low number of radiocarbon dates. ${ }^{38}$

Our main concern here is the chronology of the fortified settlements of the Vatya culture and of the Koszider horizon, traditionally regarded as marking the end of the so-called tell cultures (amongst them, the Vatya culture). In the conventional Hungarian chronological framework, the so-called Koszider period (RB B, ca. 16001500/1450 BC) corresponds to the last phase of the Middle Bronze Age and, at the same time, it also represents the transition to the Late Bronze Age. The interpretation of this period is hotly debated among archaeologists working in Hungary and in the westerly regions of Central Europe. The deposition of the so-called Koszider hoards was traditionally linked to the attacks of the mobile pastoralist warriors of the "Tumulus culture" arriving from Southern Germany, whose arrival brought an end to the flourishing "tell cultures" along the Danube and the Tisza. ${ }^{39}$ In this interpretation, the Koszider period was regarded as brief interlude of turbulence and war, which was followed by the classical Tumulus period (RB C, $c a$. 1500/1450-1300 BC). More recently, however, the period is not seen as a
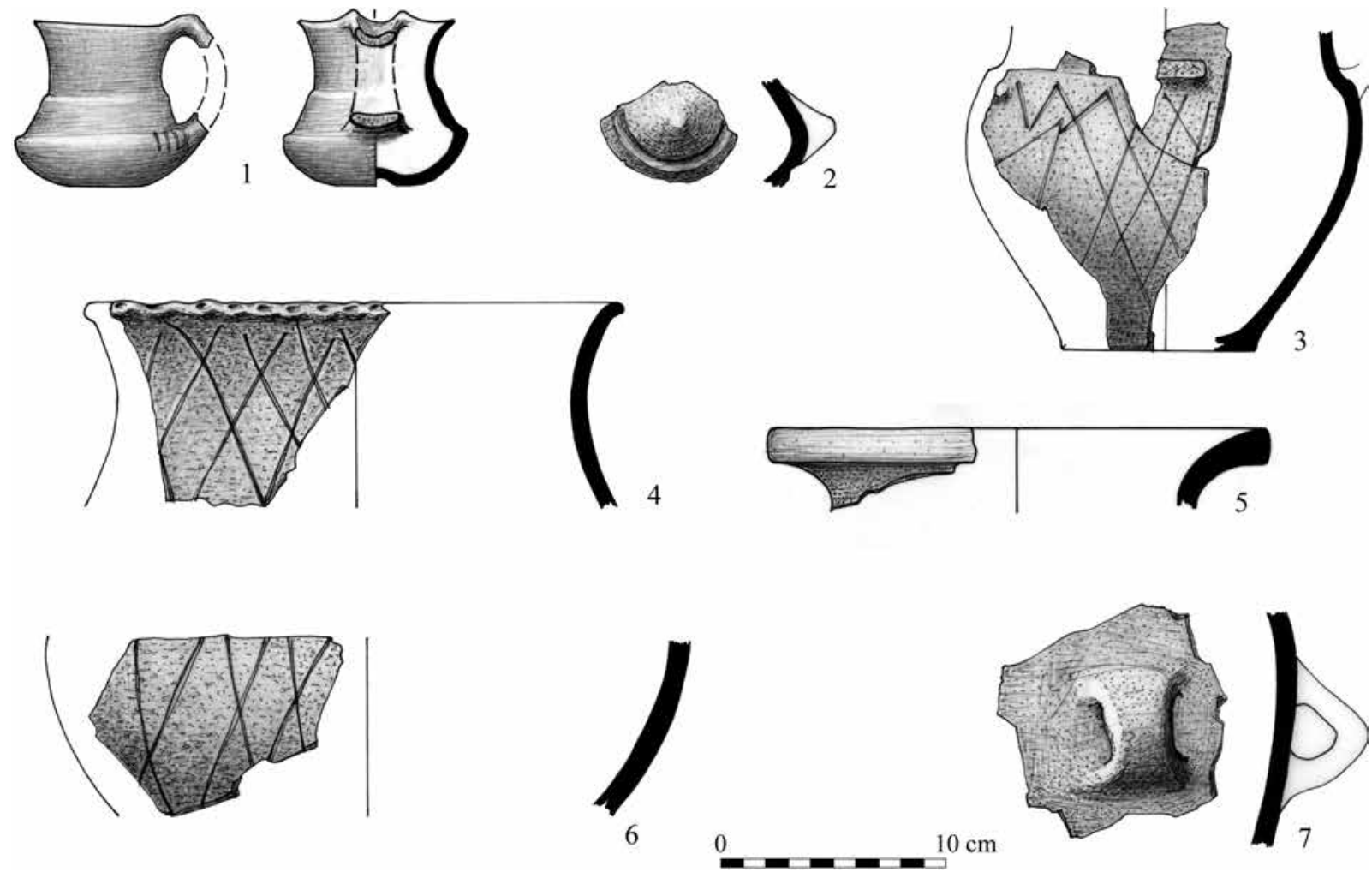

Fig. 12. Kakucs-Balla-domb. 1-7: Selection of finds from Unit A/5/5 while clearing Level 2

${ }^{36}$ DAVID 2002, 3-46. It is symptomatic that the author did not use any of the chronological systems he referred to, and instead employed the classical terminology of the scheme proposed by P. Reinecke.

${ }^{37}$ GogÂLtan 1998, 191; GogÂltan 1999; David 2002, 3.
${ }^{38}$ GÖRSDORF 2002; RACZKY-HERTELENDI-HORVÁTH 1992; ROEDER 1992; FORENBAHER 1993; ILON 1999; KOÓS 2002; GÖRSDORFMARKOVÁ-FuRMÁNEK 2004, 79-80, Fig. 1; IlON 2007; Koós 2009; KOÓS 2010; UHNÉR 2010.

${ }^{39}$ Mozsolics 1957; BónA 1958; Mozsolics 1967. 

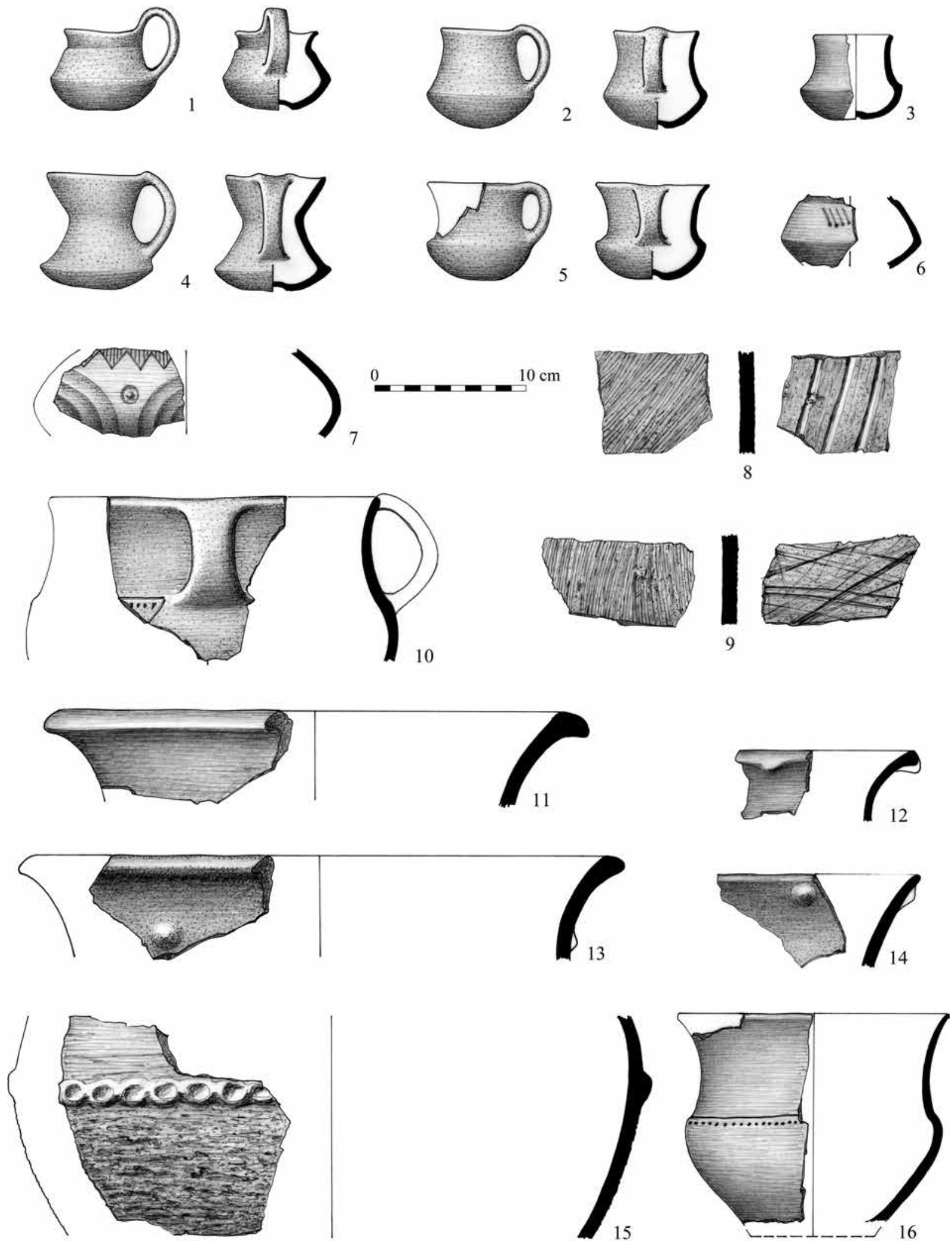

Fig. 13. Kakucs-Balla-domb. 1-16: Selection of finds from Features A/4-5 

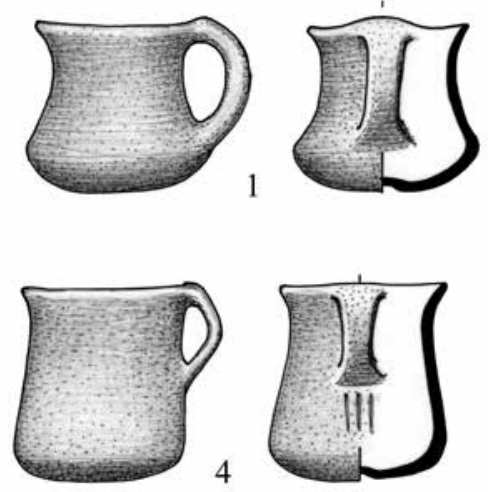

2
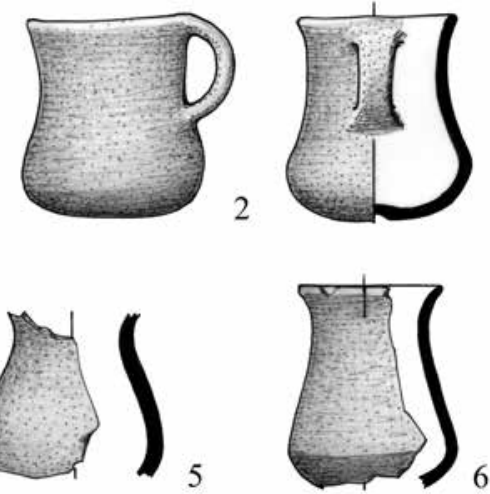

6
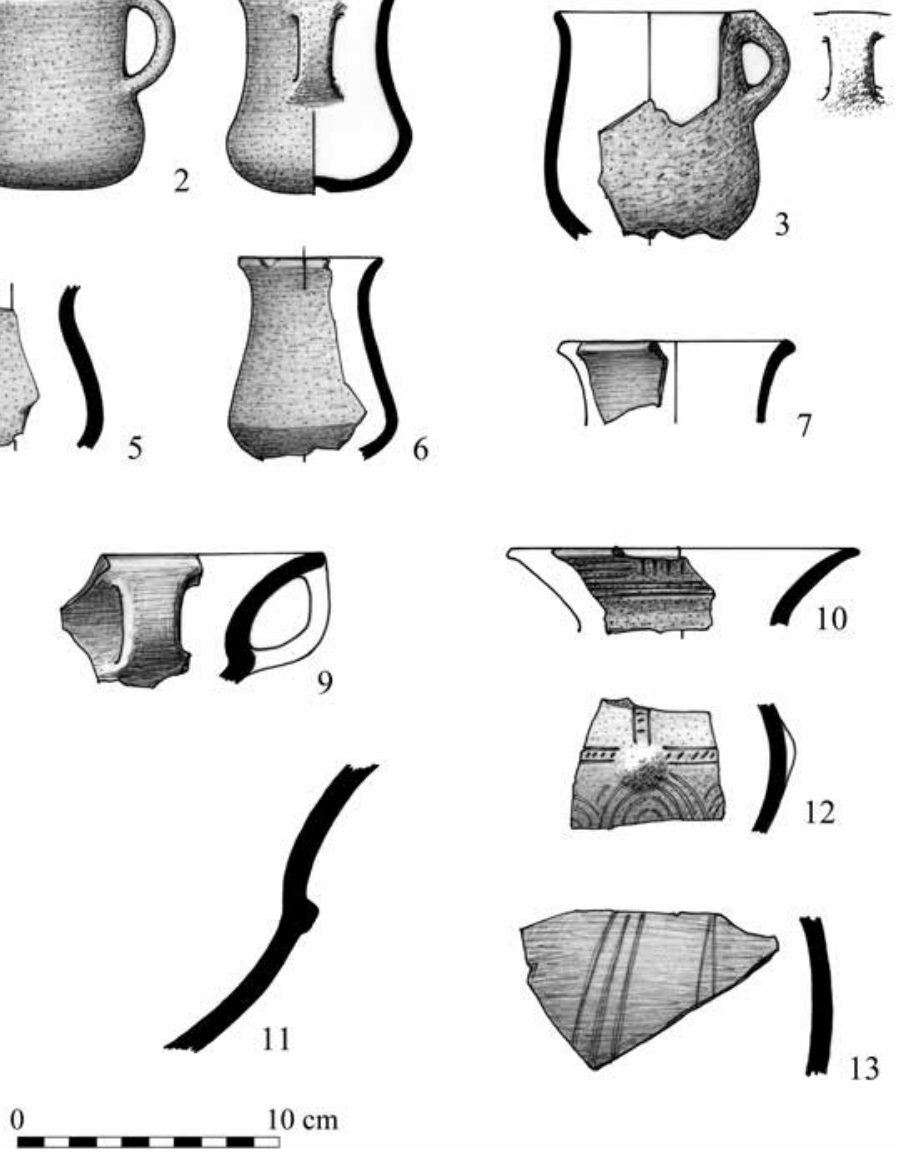
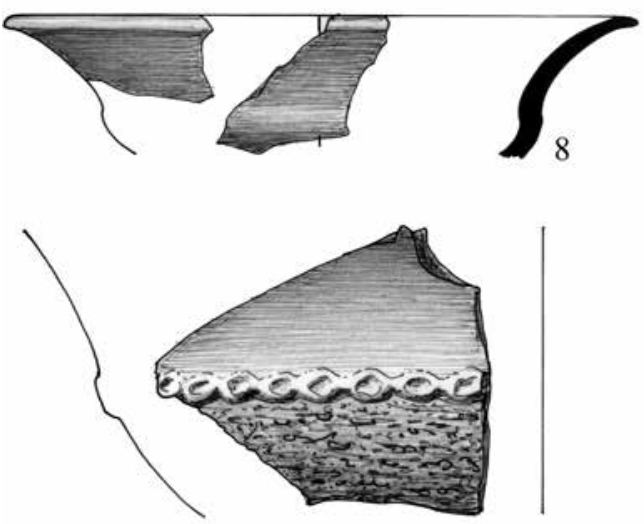

$10 \mathrm{~cm}$

Fig. 14. Kakucs-Balla-domb. 1-13: Selection of finds from Pit A/9

"horizon" linked to a specific set of events, but rather as a longer period representing a cultural peak in the Bronze Age of the Carpathian Basin, whose end was marked by profound transformations. ${ }^{40}$

The classical periodization of the Vatya culture into three phases, Vatya I (sub-phases a and b), Vatya II and Vatya III, was proposed by I. Bóna. ${ }^{41} \mathrm{He}$ correlated the three sub-periods with the main divisions of the Middle Bronze Age he had distinguished. ${ }^{42}$ The Vatya sequence ends with the Koszider period..$^{43}$ Although I. Bóna had originally assigned this period to the Late Bronze Age, it is now generally associated with the Middle Bronze Age. ${ }^{44}$

According to the generally accepted Hungarian chronological framework, as elaborated by T. Kemenczei, T. Kovács and N. Kalicz, the emergence of the Vatya culture (Vatya I) is linked to the onset of the MBA 1, Vatya II roughly corresponds to the MBA 2, while MBA 3 can be equated with the culture's late variants (Vatya-Koszider, Alpár, Rákospalota). ${ }^{45}$

press.

${ }^{40}$ Poroszlai 2003b; RemÉnYi 2005; P. Fischl et al. in

${ }^{41}$ BÓNA 1975, 25, 73; cp. KReITER 2007, 33.

${ }^{42}$ Cp. KovÁcs 1984, 223.

${ }^{43}$ The controversies concerning the Koszider horizon are reflected in the labels attached to this period. It is variously referred to as Vatya-Koszider horizon, period, phase or even culture (MozsoLICS 1988, 42; BÓNA 1992b, 58-64, with additional literature) and the label is then used to describe discrete phenomena such as the deposition of hoards and settlement development. This picture is fur- ther complicated by the ever-growing number of cultural groups, which are then used as synonyms for the Koszider horizon: e.g., Streda nad Bodrogom/Bodrogszerdahely phase (Otomani-Füzesabony culture), Alpár phase, Rákospalota phase (Vatya culture) (cp. BÓNA 1992a, 17).

${ }^{44}$ BÓNA 1992a; BónA 1992b; DAVID 2002, 21, note 131; Poroszlai 2003b, 161.

${ }^{45}$ DAVID 1998, 232-233; DAVID 2002, 32, Abb. 2. 7; 34,

Acta Archaeologica Academiae Scientiarum Hungaricae 64, 2013 

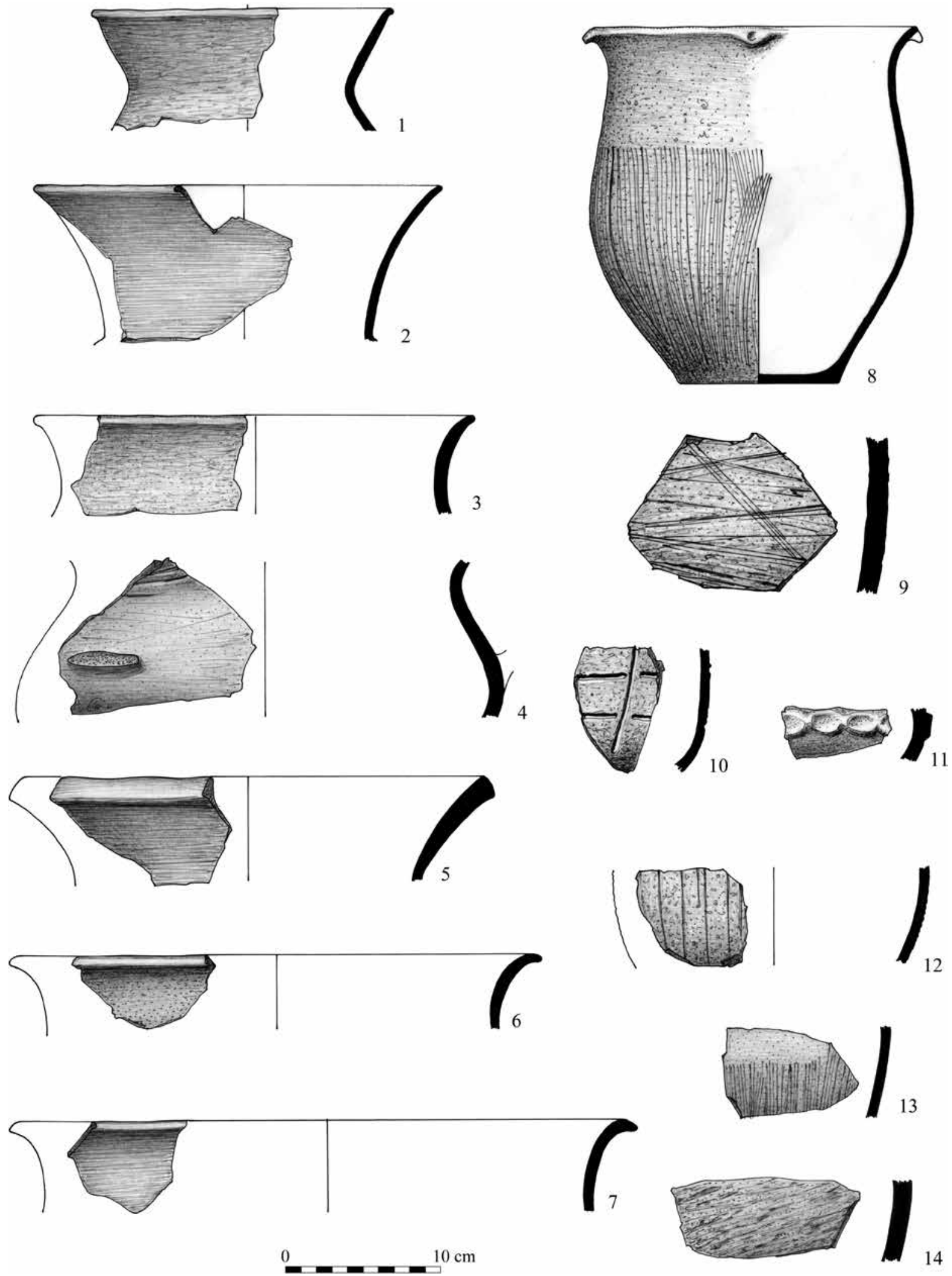

Fig. 15. Kakucs-Balla-domb. 1-14: Selection of finds from Pit A/9

Acta Archaeologica Academiae Scientiarum Hungaricae 64, 2013 

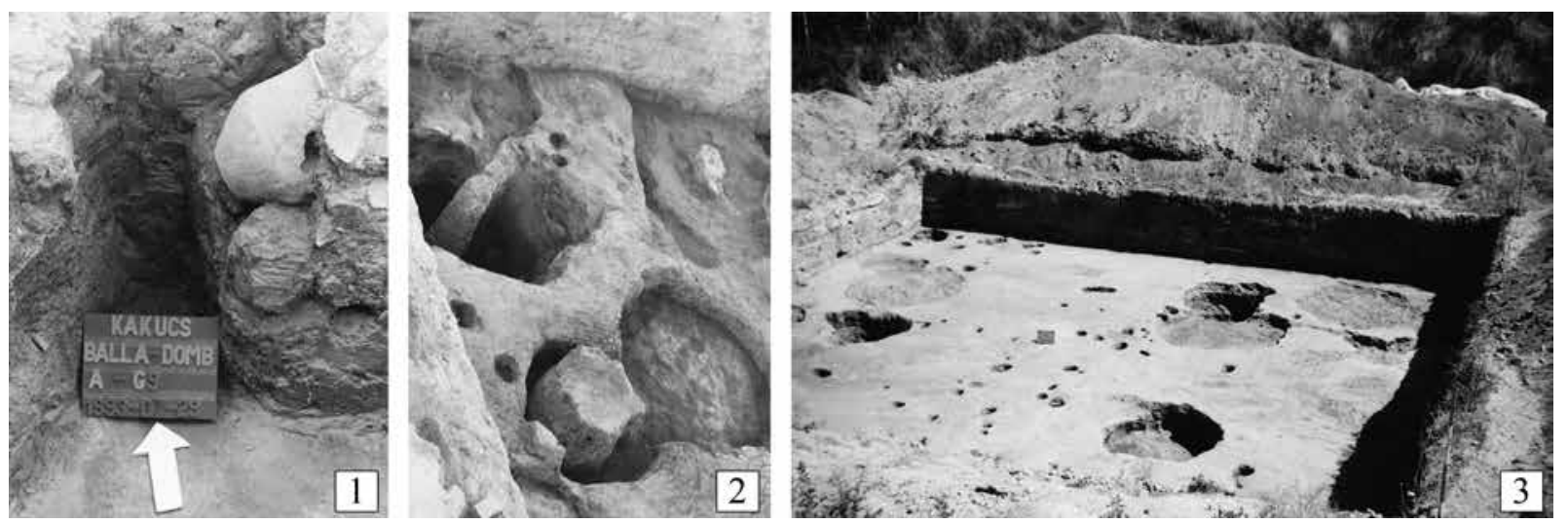

Fig. 16. Kakucs-Balla-domb. 1: Pit A/9; 2: Level 4; 3: prehistoric humus level with pits and post-holes
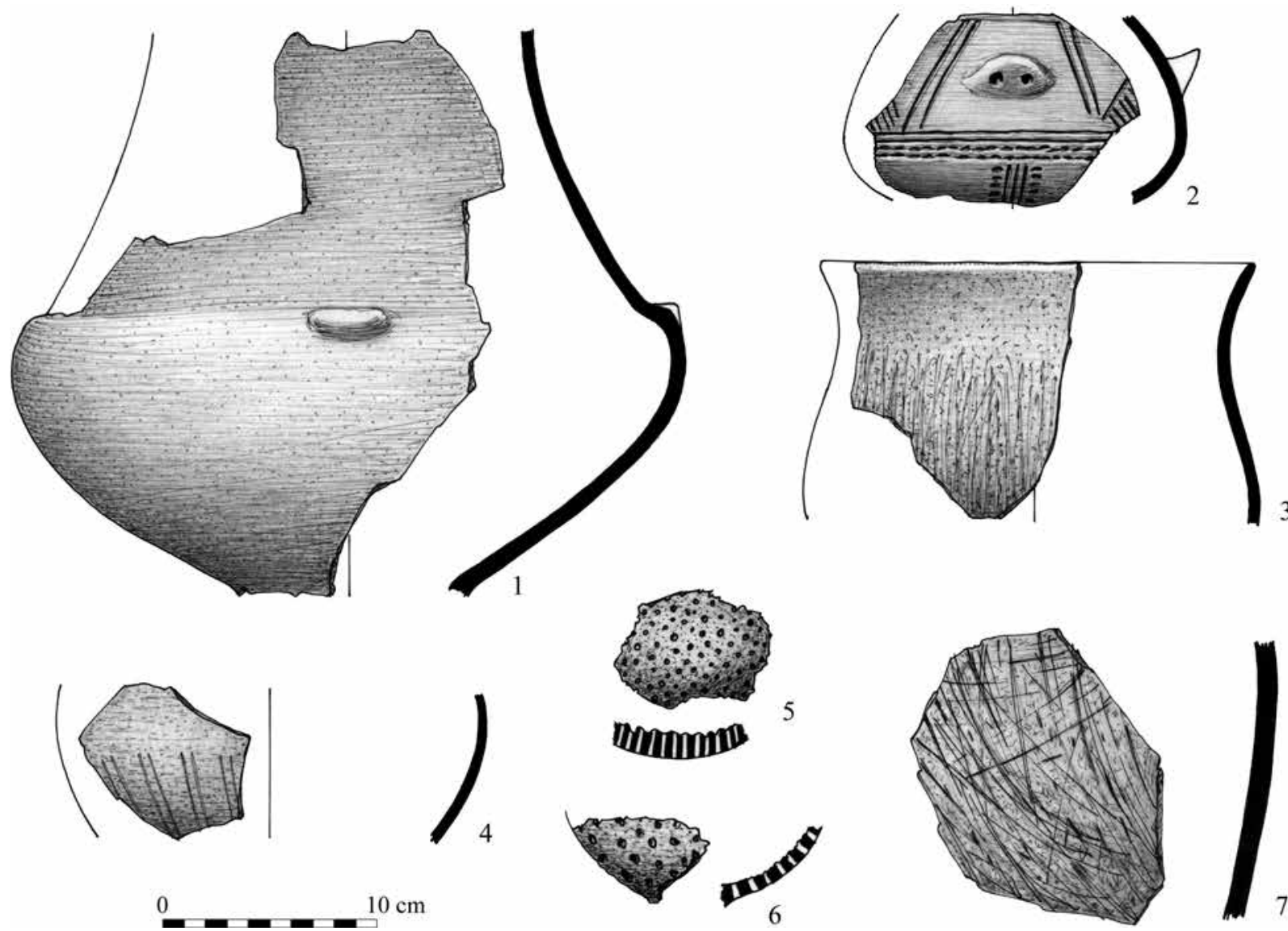

Fig. 17. Kakucs-Balla-domb. 1-7: Selection of finds from Pit A/15 

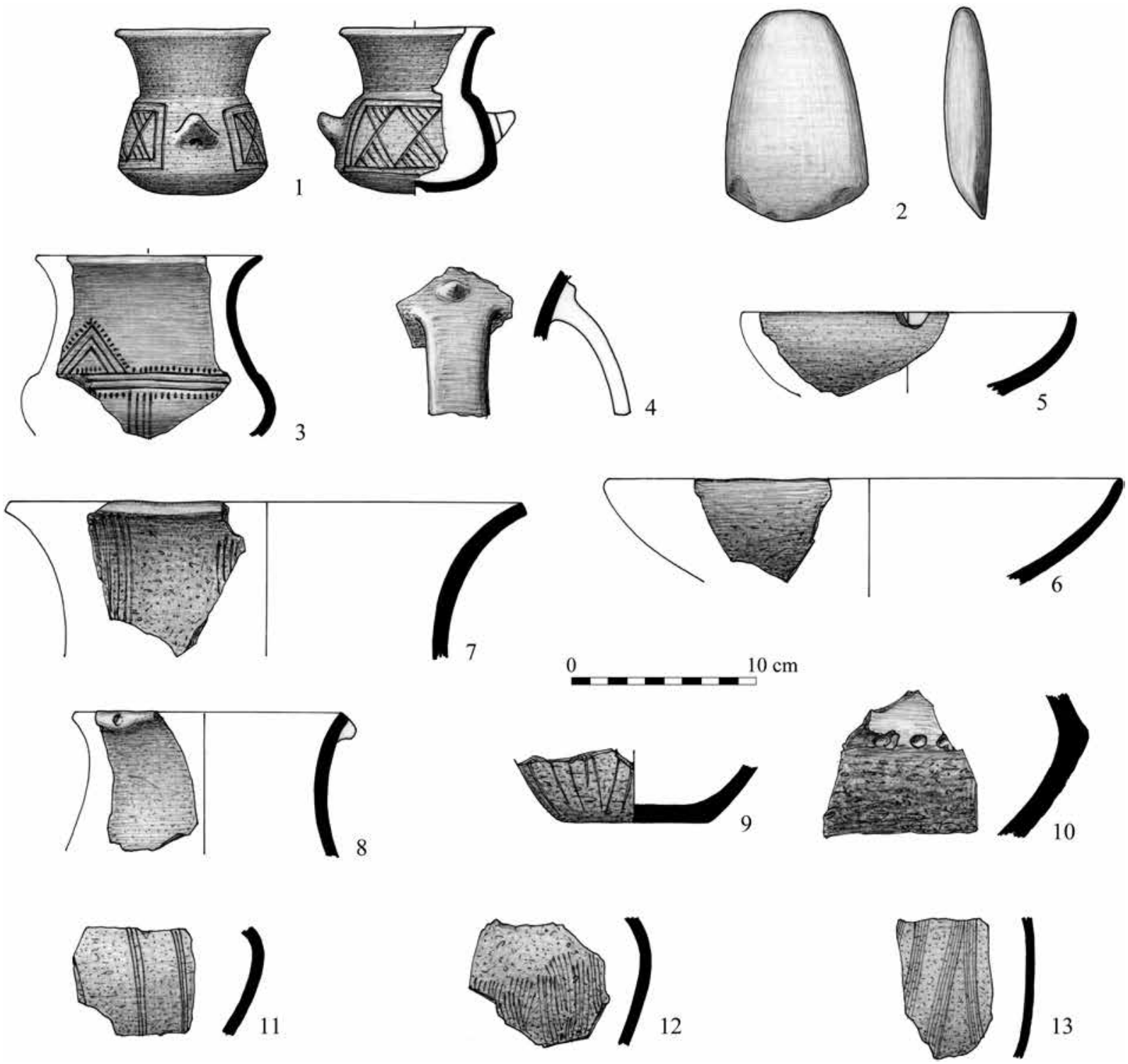

Fig. 18. Kakucs-Balla-domb. 1-13: Selection of finds from Pit A/14

In F. Gogâltan's view, Vatya I is co-eval with his Horizon 3 of the tell culture development (the turn of the EBA 3 and the MBA 1; ca. 2300-1950 BC), Vatya II with Horizon 4 (MBA 2; ca. 1900-1700 BC) and Vatya III with Horizon 5 (MBA 3; ca. 1650-1500 BC). ${ }^{46}$

I. Bóna outlined a different chronological scheme in the catalogue accompanying the exhibition Bronzezeit in Ungarn. ${ }^{47}$ Drawing on an outdated Bronze Age chronology, he proposed a general chronology for the Vatya culture, which in his view spanned the period between $\mathrm{ca} .1650$ and $1350 \mathrm{BC}{ }^{48}$ In this chronology, Vatya I and Vatya

${ }^{46}$ GogÂltan 2005; GoGÂLtan 2008, 40-41, Fig. 2.

${ }^{47}$ MeIER-ARENDT 1992. A French version of the catalogue Le bel Âge du Bronze en Hongrie (sous la dir de J. L. Coudrot, J. P.
Thévenot, Budapest 1994) without any substantial changes was also published.

\footnotetext{
${ }^{48}$ Meier-Arendt 1992, 40.
} 


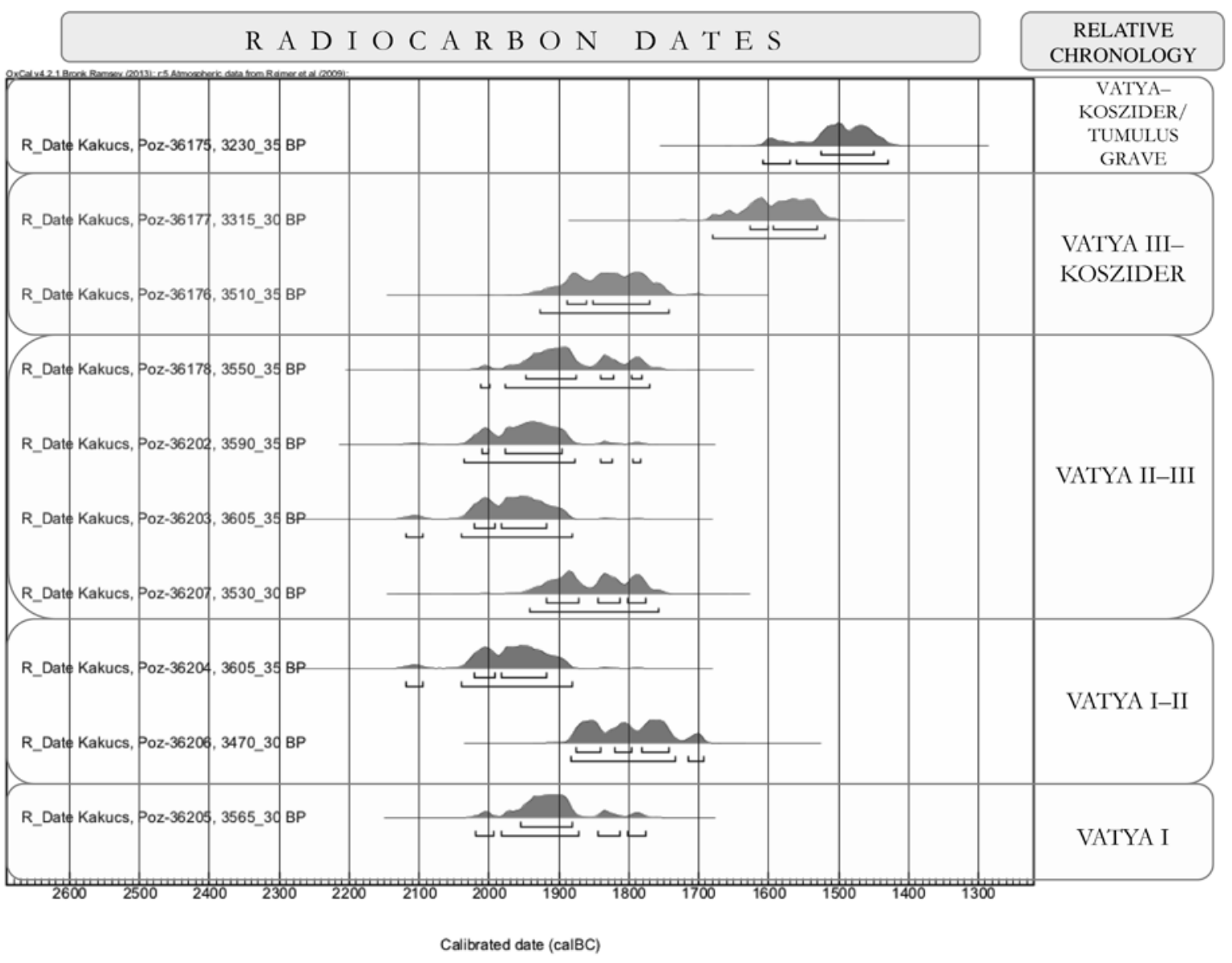

Fig. 19. Kakucs-Balla-domb. The sum of the probability distribution of the radiocarbon dates for Phases I-II-III and the Koszider period of the Vatya culture (JAEGER 2011)

II were linked to the MBA 1, Vatya III to the MBA2, and the late variants (Vatya-Koszider, Alpár, Rákospalota and late Vatya-Koszider) to the MBA $3 .^{49}$

In her assessment of the Dunaújváros-Duna-dülő cemetery, M. Vicze outlined the following sequence and relative chronology for the burial ground (although without assigning absolute dates to individual periods): formative Vatya-Kisapostag 2 (EBA 3; RB A1), Vatya I-Kisapostag 3 (MBA 1; RB A1), Vatya II, Vatya II-III (MBA 2; RB A2), early and late Koszider phase (MBA 3; RB B1), Rákóczifalva group-Tumulus culture (LBA 1; RB B2). ${ }^{50}$

Some of the Vatya sites were occupied continuously from the Early Bronze Age onward (the Nagyrév culture) ${ }^{51}$ The available stratigraphic data indicate that during the initial and the early Vatya occupation, these sites were open settlements and that fortifications were mainly constructed during the late Vatya period. ${ }^{52}$ Other settlements, however, were demonstrably established during the late Vatya period. ${ }^{53}$

As mentioned above, the decline of fortified settlements and, more broadly, the collapse of the tell cultures of the Carpathian Basin are generally linked to the Koszider period. Traditionally, the abandonment of the tell sett-

${ }^{49}$ BÓNA 1992a, 17; DAvid 2002, 30, Abb. 2. 6.

${ }^{50}$ ViCZE 2011, 156, Fig. 31. Currently, there are no absolute dates for the culture's cemeteries, and the Dunaújváros-Dunadülö burial ground is no exception. The typochronological analyses were based on the grave assemblages from these cemeteries. The lack of radiocarbon dates can in part be attributed to the custom of cremating the dead.

${ }^{51}$ MeIER-Arendt 1992, 40; David 1998, 231.

${ }^{52}$ DAvid 1998, 234.

${ }^{53}$ BÓNA-NovÁKi 1982, 112, 115; KovÁcs 1982, 289; PoROSZLAI 1991b, 59. 


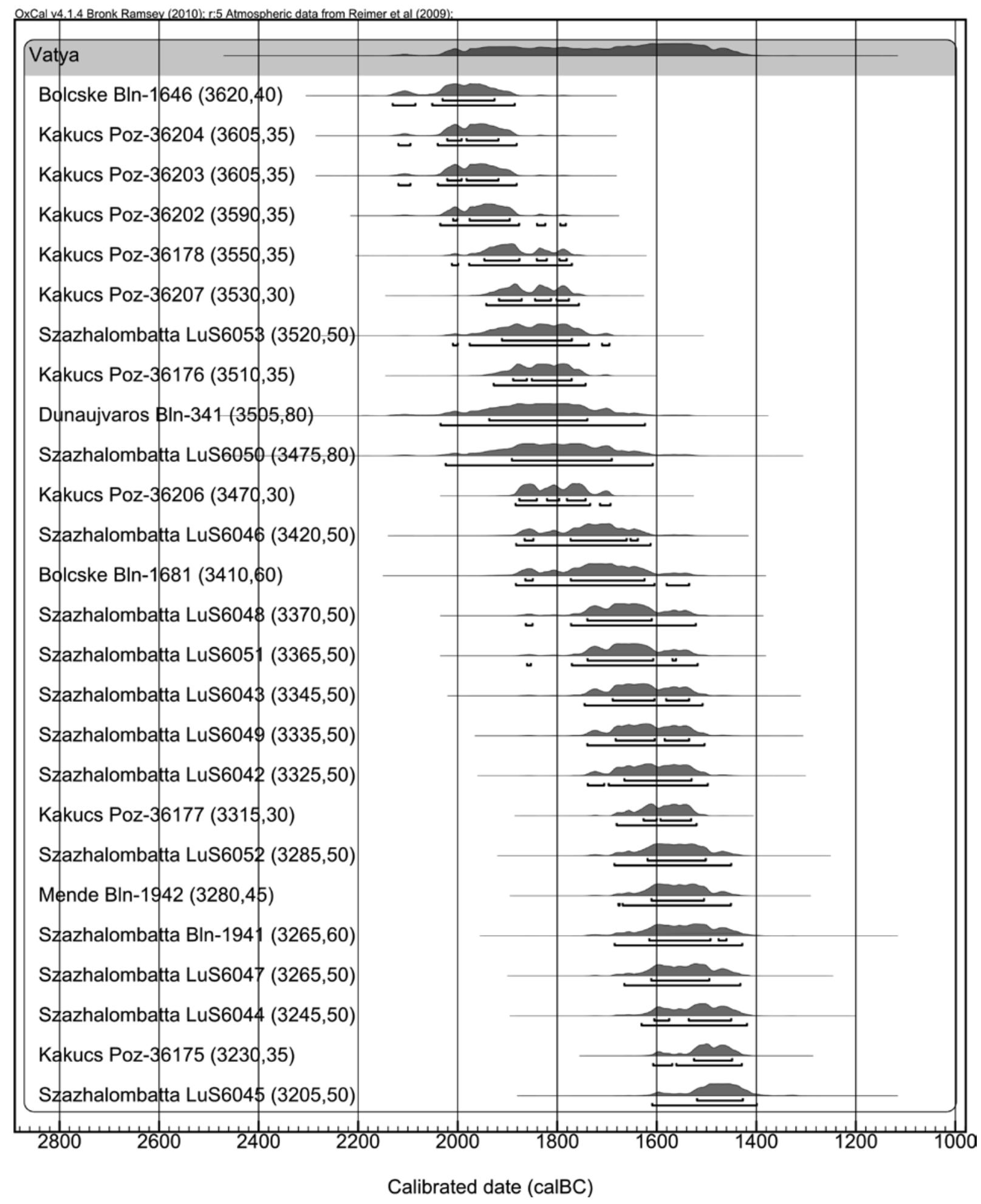

Fig. 20. The sum of the probability distribution of radiocarbon dates from the defensive settlements of the Vatya culture (after RACZKY-HERTELENDI-HORVÁtH 1992; FORENBAHER 1993; UHNÉR 2010; JAEGER 2011) 


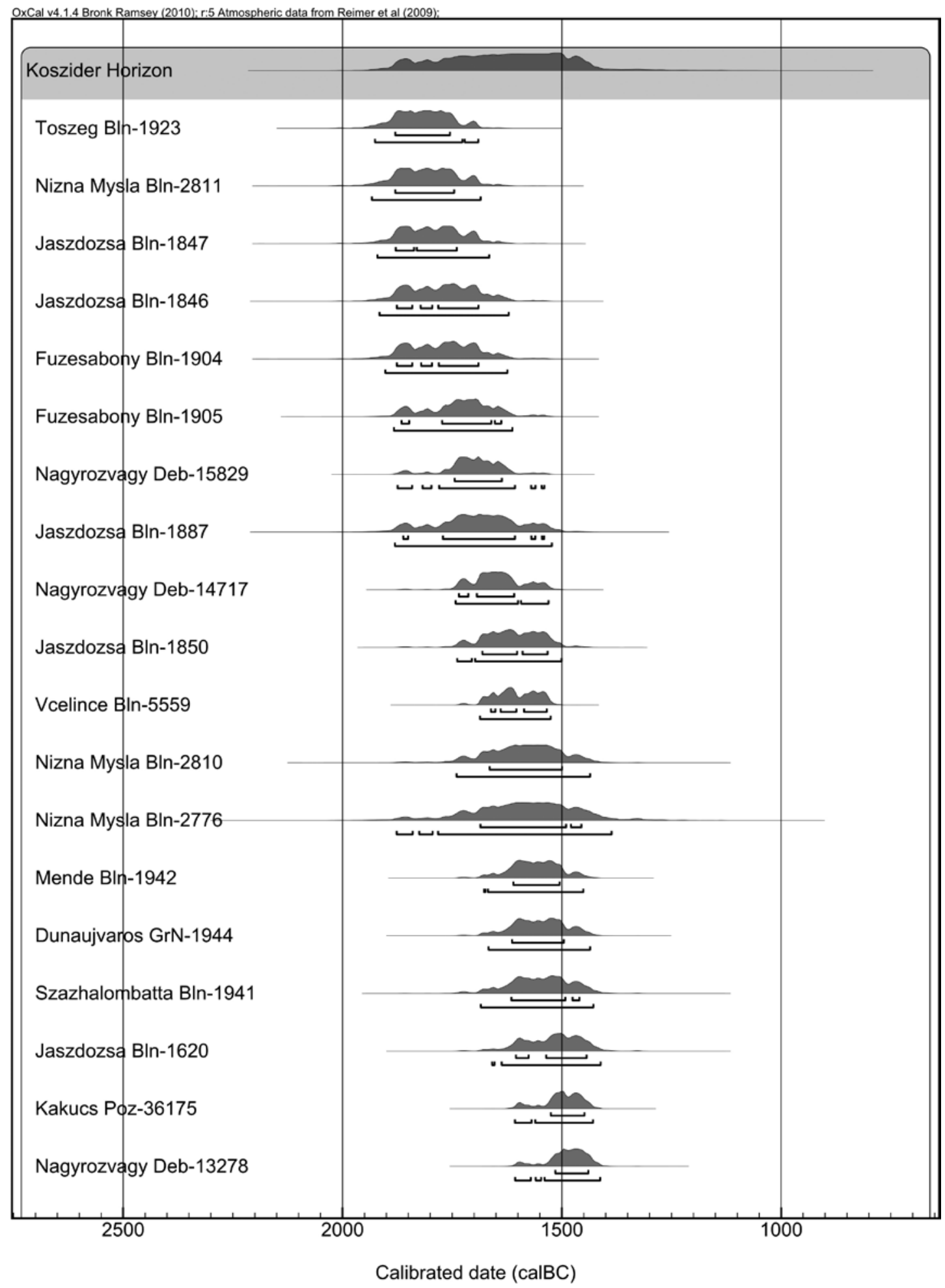

Fig. 21. The sum of the probability distribution of radiocarbon dates connected with the Koszider period (after RACZKY-HERTELENDI-HoRváth 1992; Forendaher 1993; GöRSDORF-MARKOVÁ-FuRMÁNeK 2004; KoÓs 2009; JAEGER 2010; KoÓs 2010; JAEGER 2011) 


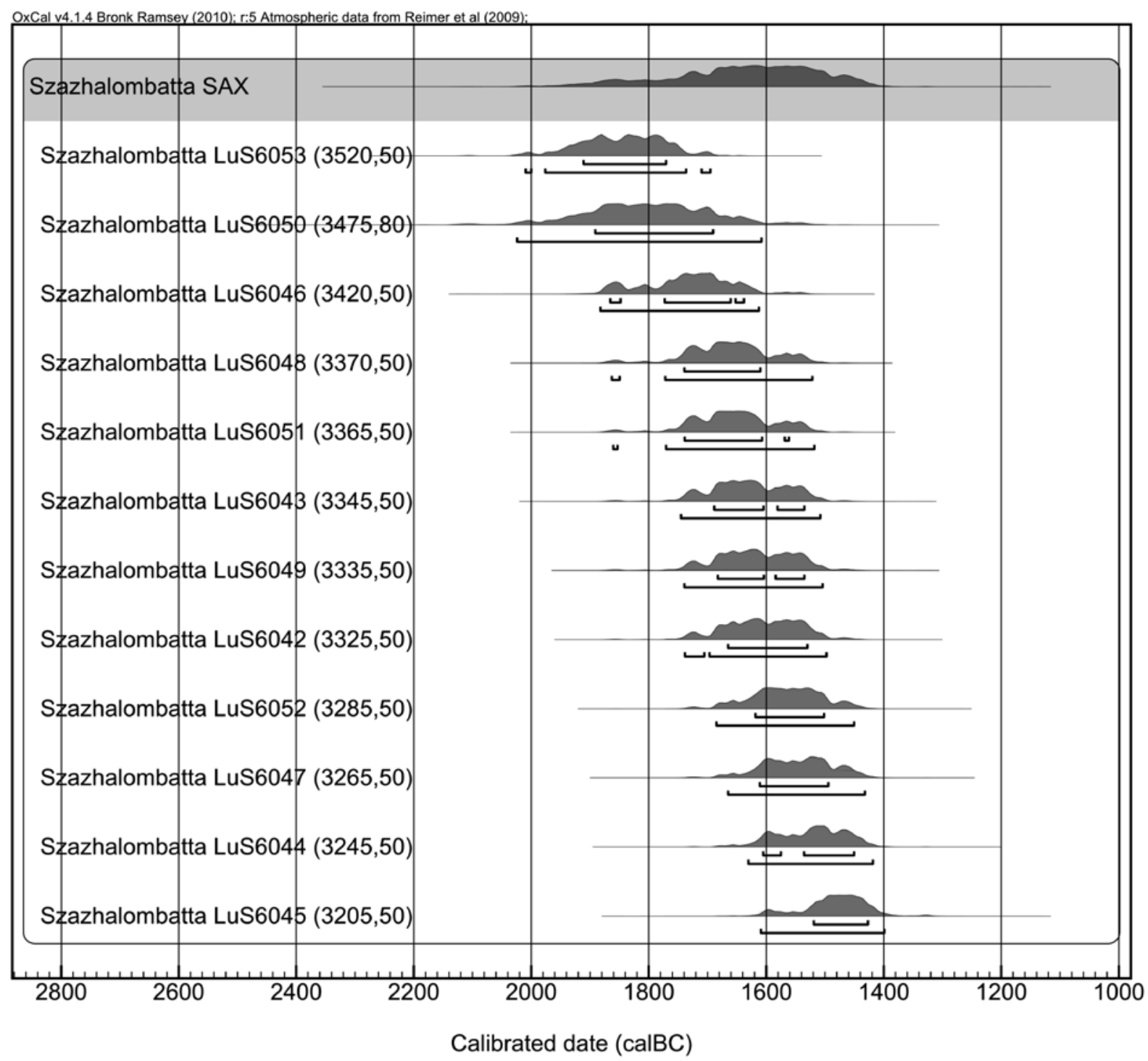

Fig. 22. The sum of the probability distribution of radiocarbon dates from the Százhalombatta-Földvár (after UHNÉR 2010; JAEGER 2011)

lements is dated to the turn of the $15^{\text {th }}$ and $14^{\text {th }}$ centuries $\mathrm{BC},{ }^{54}$ with the line most often drawn at $c a .1350 \mathrm{BC}$ as marking the end of the occupation on fortified settlements. ${ }^{55}$

Until recently, there were only a handful of radiocarbon dates, which did not enable an absolute dating of the Vatya sequence (see in Appendix). ${ }^{56}$ The most complete list of radiocarbon dates appeared in the Bronzezeit in Ungarn catalogue mentioned above. ${ }^{57}$ However, the information accompanying the dates lacks basic data such as the provenance of the samples within a particular site and the material on which the dating was performed. This is the main reason that they cannot be regarded as a sound basis for drawing conclusions. The likelihood of an erroneous interpretation based on these dates is amply illustrated by dates from Sample Bln-341 for Dunaújváros-Koszi-

${ }^{54}$ Poroszlai 1991b, 66; Meier-Arendt 1992, 40.

${ }^{55}$ KovÁCS 1982, 289; PorosZlaI-VICZE 2004, 231.

\footnotetext{
${ }^{56}$ FORENBAHER 1993, 244-245, 251, Fig. 11.

${ }^{57}$ RACZKY-HERTELENDI-HORVÁTH 1992.
} 
derpadlás and the dates for Bölcske-Vörösgyír/Vörösgyürü. The former was obtained from charred grain which was reportedly recovered from layers associated with the Nagyrév culture. ${ }^{58}$ The results of the measurements however gave a date more in line with the settlement's Vatya occupation (Bln-341; 3505 80 BP, 1937-1740 [68.2\%] cal BC, 2035-1624 [95.4\%] cal BC). ${ }^{59}$ However, this can no longer be clarified owing to the lack of any field documentation regarding the context of the sample. As far as the Bölcske dates are concerned, the technique of excavating a site by spade spits (the Spatenstichtechnik) ${ }^{60}$ as was customary at the time, means that few, if any, reliable stratigraphic and contextual observations were made. The overall impression of a general chaos in the available information is further enhanced by the different dates specified for one sample in the available publications. ${ }^{61}$ This is illustrated by the dates given for the samples from Mende-Leányvár (Bln-1942) and Tószeg (Bln-1923). The discrepancy between the Mende dates is relatively small (20 years) and involves a laboratory error $\left(3280 \pm 45 \mathrm{BP}^{62}\right.$ vs. $\left.3280 \pm 65 \mathrm{BP}^{63}\right)$, while the Tószeg dates are characterised by both a laboratory error (5 years) and a 100 years difference in the specified BP age $\left(3490 \pm 45 \mathrm{BP}^{64}\right.$ vs. $\left.3590 \pm 50 \mathrm{BP}^{65}\right)$.

The only information on the material of the samples comes from Dunaújváros (charred grain). ${ }^{66}$ The dates published in the Bronzezeit in Ungarn catalogue were broadly associated with the Vatya culture, but without any reference to typochronology or a particular period in the Vatya sequence. ${ }^{67}$ In view of the above, they contribute little to the refinement of the internal periodisation of the Vatya culture and the absolute chronology of the fortified settlements in the Vatya distribution. ${ }^{68}$

The five radiocarbon dates for the Vatya culture published in the Bronzezeit in Ungarn catalogue obtained from samples collected at Bölcske (2 dates), Dunaújváros, Mende and Százhalombatta gave a date between $c a$. 2000-1600/1500 BC (Fig. 20). ${ }^{69}$

Although several dates are available for the Koszider period, they come from a fairly extensive and culturally much more diverse area. The known dates are based on samples from sites of the Hatvan, Otomani-Füzesabony and Vatya cultures. ${ }^{70}$ They demonstrate a relatively long period between 1950/1900-1500/1450 cal BC, grouped in two time brackets between ca. 1950/1900-1650 (95.4\%) cal BC and 1650-1500/1450 (95.4\%) cal BC (Fig. 21). Since there is virtually no information about the archaeological context of the samples, it is impossible to make any meaningful comment on the relative lateness of the date from Sample Bln-1217 from the Jászdózsa settlement (3105 \pm 100 BP;1 1496-1221 [68.2\%] BC, 1612-1057 [95.4\%] cal BC). What is crucial, however, is that this date, together with the latest one of the Kakucs-Balla-domb series (Poz-36175; 3230 35 BP; 1526-1449 [68.2\%] cal $\mathrm{BC}, 1608-1430$ [95.4\%] cal BC) falls after $1500 \mathrm{BC}$, indicating a late date for the decline of fortified settlements in the Carpathian Basin (Table 1).

Even though the dates quoted in the above lack any information on the archaeological context of the samples, they nonetheless suggest that the Koszider period and the cultural transformation associated with this period in the Carpathian Basin was more complex and lasted for fairly long period of time. ${ }^{72}$ Traditionally, the Koszider hoards are linked to the late phase of the Otomani-Füzesabony, Madarovce and Vatya cultures. Hoards of this type were no longer deposited after the decline of these cultures, although some of the artefact types in them continued to be manufactured and used as shown by their typologically later types. ${ }^{73}$

${ }^{58}$ QUITTA-KOHL 1969, 241.

${ }^{59}$ RACZKY-HERTELENDI-HORVÁTH 1992, 45.

${ }^{60}$ Poroszlai 1999-2000, 113.

${ }^{61}$ The published dates for Sample 1942 from MendeLeányvár come from two different laboratories: Hannover (FORENBAHER 1993, 245) and Berlin (RACZKY-HERTELENDI- HoRVÁTH 1992, 45). In addition, T. Kovács mentions that this date was obtained in the ${ }^{-14} \mathrm{C}$ Laboratory of the Niedersächsisches Landesamt für Bodenforschung (see in Hannover) (KovÁcs 1973, 12, and note 10). There is no information suggesting that several measurements were made on one sample originating from the Mende-Leányvár site.

${ }^{62}$ RACZKY-HERTELENDI-HORVÁTH 1992, 45.

${ }^{63}$ FoRENBAHER 1993, 245.
${ }^{64}$ RACZKY-HERTELENDI-HORVÁTH 1992, 45.

${ }^{65}$ GÖRSDORF-MARKOVÁ-FuRMÁNEK 2004, 90.

${ }^{66}$ QUiTTA-KOHL 1969, 241.

${ }^{67}$ RACZKY-HERTELENDI-HORVÁTH 1992, 45.

${ }^{68}$ JAEGER 2011, 97-112.

${ }^{69}$ RACZKY-HERTELENDI-HorvÁth 1992; ForEnbaher 1993, 244-245, 251; UHNÉR 2010; JAEGER 2011.

${ }^{70}$ RACZKY-HERTELENDI-HORVÁtH 1992; ForENBAHER 1993; Koós 2002; GörsdorF-MarkovÁ-FurmáneK 2004; KoÓs 2009; JAEGER 2010, 315-317; KoÓs 2010; JAEGER 2011, 111-112.

${ }^{71}$ RACZKY-HERTELENDI-HORVÁTH 1992, 43.

${ }^{72}$ JAEGER 2010.

${ }^{73}$ NovotNÁ 1998, 357. 
The recently obtained dates for Százhalombatta-Földvár, Érd ${ }^{74}$ and Kakucs-Balla-domb ${ }^{75}$ contribute to our knowledge of the chronological dimensions of the occupation on various Vatya settlements. A series of twelve dates spanning the period between 1900 and 1400 BC is now available for Százhalombatta (Fig. 22). ${ }^{76}$ The samples from open settlement at Érd roughly fall into the same period.

Knowing that the Százhalombatta settlement was occupied throughout the Vatya sequence, the lack of precise information on the relation between the dates and a particular typological phase or stratigraphic level is particularly distressing. In the case of the ten dates for Kakucs-Balla-domb, we know that they can be associated with Vatya I-II, Vatya II-III and Vatya III-Koszider, and that they fall within the period from 2000/2050 to 1450 BC (Fig. 19, Table 1). At present, it is not possible to link the different sub-phases to absolute dates. ${ }^{77}$ Aside from possible sampling errors, the separation of the successive typochronological phases/sub-phases within the Vatya sequence is also uncertain on the culture's settlements. ${ }^{78}$ At present only so much can be said, that the occupation of the Kakucs settlement began around 2000/1900 BC. The dates for the early Vatya period (Vatya I-II) show a scatter between 2000/1900 and 1800/1700 BC. The currently known dates for the classical Vatya II-III period partly overlap with the early period, although most fall between 1900/1800 and 1800/1700 BC. The late Vatya III-Koszider period can be dated to around 1600-1500 BC. The date of final occupation phase, 1526-1449 (68.2\%) cal $\mathrm{BC}$, is indicated by the burial dug into the earlier occupation levels.

The reliability and accuracy of the radiocarbon-based chronology outlined above can only be confirmed by additional dates for the Vatya culture and the correlation of the Százhalombatta-Földvár series with specific occupation phases and Vatya sub-periods. The dates from Százhalombatta-Földvár and Kakucs-Balla-domb indicate that the decline of the Vatya culture lasted longer than the dates quoted from the Bronzezeit in Ungarn catalogue would suggest. The occupation of the (fortified) settlements can be maximally defined as spanning the period between 2000/1900-1500/1450 BC (Appendix and Fig. 20).

It must also be noted that it is still virtually impossible to determine the chronology of the key periods in settlement development: the Nagyrév/Vatya cultural transformation documented at some sites, ${ }^{79}$ the date when the initially open Vatya settlements were fortified (e.g., at Dunaújváros, Százhalombatta-Földvár and Pákozd-Vár) ${ }^{80}$ and the period when new fortified settlements appeared following the culture's expansion as postulated in Bronze Age studies (e.g., Alpár-Várdomb, Mende-Leányvár, Nagykörös-Földvár). ${ }^{81}$ Still, the increase in the number of radiocarbon dates available for a particular settlement (Százhalombatta-Földvár, Kakucs-Balla-domb) will no doubt remedy this situation. Building a full series of radiocarbon dates correlated with the complete stratigraphic sequence of individual sites will surely help to overcome the current obstacles in reconstructing the dynamics of fortified Vatya settlements.

\section{ACKNOWLEDGEMENTS}

This paper was supported by grants from Ministry of Science and Higher Education of the Republic of Poland (NN 109 217135); the National Science Centre of The Republic of Poland (2012/05/BS3/03714), the Hungarian Scientific Research Fund and the Hungarian Academy of Sciences. We would like to thank Zsolt Réti and Margit Szabados for the illustrations.

\footnotetext{
${ }^{74}$ UHNÉR 2010, 347-348.

${ }^{75}$ JAEGER 2011.

${ }^{76}$ Although the list specifies twenty samples, only twelve are associated with the Vatya culture (UHNÉR 2010, 347), and therefore only these samples were considered here.

${ }^{77}$ Cp. Gogâltan 2005; GogÂLtan 2008.
}

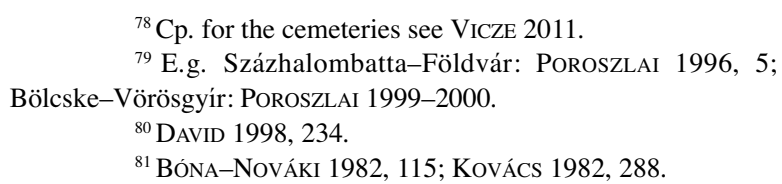

${ }^{78} \mathrm{Cp}$. for the cemeteries see VICZE 2011.

${ }^{79}$ E.g. Százhalombatta-Földvár: Poroszlai 1996, 5; Bölcske-Vörösgyír: PoRoszLaI 1999-2000.

${ }^{80}$ DAVID 1998, 234.

${ }^{81}$ BÓNA-NOVÁKI 1982, 115; KovÁCS 1982, 288. 


\section{REFERENCES}

BÁNDI 1960

BÁNDI 1966

BÓNA 1957

BÓNA 1958

BÓNA 1975

BÓNA 1992a

BÓNA 1992b

BÓNA-NovÁKI 1982

\section{CZagáNYI 1995}

CZAGÁNYi 2000

CZAJLIK-BÖDŐCS-RUPNIK 2010

CzAJLiK et al. 2008

DAVID 1998

DAVID 2002

EARLE-Kolb 2010

EARLE-KRISTIANSEN 2010

EARLE et al. 2011

ENDRŐDI-FELD 1980

ENDRŐDI-GYULAI 1999

P. FISCHL-GUBA 2010

P. FISCHL et al. in press

FORENBAHER 1993

GoGÂLTAN 1998
= G. BÁNDI: Előzetes jelentés a Sárbogárd-Cifrabolondváron végzett 1959. évi ásatásról (Vorbericht über die Ausgrabungen des Jahres 1959 in Sárbogárd-Cifrabolondvár). Alba Regia 1 (1960) 149153

= G. BÁNDI: The cemetery of Ercsi-Sinatelep. The situation of the Szigetszentmiklós-Kisapostag group of the Nagyrév culture in the history of the Early Bronze Age in North-Eastern Transdanubia. Alba Regia 6-7 (1965-66 [1966]) 11-25.

= I. BóNA: Az ürbőpusztai avar temető (Le cimetière avar de Ürbőpuszta). ArchÉrt 84 (1957) 155-174.

= I. BónA: Die Chronologie der Hortfunde vom Koszider Typus. ActaArchHung 9 (1958) 213-243.

= I. BóNA: Die mittlere Bronzezeit Ungarns und ihre südöstlichen Beziehungen. ArchHung 49. Budapest 1975.

= I. BónA: Bronzezeitliche Tell-Kulturen in Ungarn. In: MeIER-ArendT 1992, 9-39.

= I. BóNA: Bronzeguss und Metallbearbeitung bis zum Ende der mittleren Bronzezeit. In: MEIERARENDT 1992, 48-65.

= I. BóNA-Gy. NovÁKI: Alpár bronzkori és Árpád-kori vára (Alpár. Eine bronzezeitliche und mittelalterliche Burg). Cumania 7 (1982) 17-268.

= L. CZAGÁNYI: Inárcs története 1263-1993 [The History of Inárcs 1263-1993]. Inárcs 1995.

= L. CZagánYi: Bugyi község története (The History of the Village Bugyi) I-II. Bugyi 2000.

$=$ Z. CZAJLIK-A. BöDŐCS-L. RUPNIK: Légi fényképezéses régészeti kutatások Magyarországon 2009ben (Rövid beszámoló az ELTE Régészettudományi Intézetének Térinformatikai Kutatólaboratóriumában folyó munkáról) (Aerial photographic archaeological investigations in Hungary in 2009. Short report on the activities of the 3D Laboratory of the Archaeological Institute of the ELTE). In: Régészeti kutatások Magyarországon 2009 (Archaeological Investigations in Hungary 2009). Ed. J. Kisfaludi. Budapest 2010, 81-111.

= Z. CZAJLIK-A. BöDŐCS-É. ĎURKOVIC-L. RuPNIK-M. WINKLER: Légi fényképezéses régészeti kutatások Magyarországon 2007-ben (Rövid beszámoló az ELTE Régészettudományi Intézetének Térinformatikai Kutatólaboratóriumában folyó munkáról) (Aerial photographic archaeological investigations in Hungary in 2007. A short report on the activities of the 3D Research Laboratory of the Archaeological Institute of the ELTE). In: Régészeti kutatások Magyarországon 2007 (Archaeological Investigations in Hungary 2007). Ed. J. Kisfaludi. Budapest 2008, 121-144.

= W. DAVID: Zum Ende der bronzezeitlichen Tellsiedlungen im Karpatenbecken. In: Archäologische Forschungen in urgeschichtlichen Siedlungslandschaften. Festschrift für Georg Kossack zum 75. Geburtstag. Hrsg. H. Küster, A. Lang, P. Schauer. Regensburger Beiträge zur prähistorischen Archäologie 5. Regensburg 1998, 231-267.

= W. DAVID: Studien zur Ornamentik und Datierung der bronzezeitlichen Depotfundgruppe Hajdúsámson-Apa-Ighiel-Zajta. Teil 1-2. Bibliotheca Musei Apulensis 18. Alba Iulia 2002.

= T. EARLE-M. KolB: Regional settlement patterns. In: EARLE-KRISTIANSEN. 2010, 57-86.

$=\mathrm{T}$. EArle-K. Kristiansen (eds): Organizing Bronze Age Societies. The Mediterranean, Central Europe and Scandinavia Compared. Cambridge: Cambridge University Press 2010.

$=$ T. EARlE-A. Kreiter-C. KlehM-J. Ferguson-M. VicZE: Bronze Age ceramic economy: the Benta Valley, Hungary. EJA 14 (2011) 419-440.

= A. ENDRŐDI-I. FELD: Régészeti kutatások a solymári Mátyás-dombon 1929-1934 (Archäologische Forschungen auf dem Mátyás-Hügel in Solymár 1929-1934). StComit 9 (1980) 267-313.

= A. ENDRŐDI-F. GYULAI: Soroksár-Várhegy - A fortified Bronze Age settlement in the outskirts of Budapest. Plant cultivation of Middle Bronze Age fortified settlements. CommArchHung 1999, 5-34.

$=\mathrm{K}$. P. FischL-Sz. GuBA: A felgyői bronzkori temető és település (The Bronze Age settlement and cemetery at Felgyő). In: Felgyő Ürmös-tanya. Bronzkori és avarkori leletek László Gyula felgyői ásatásának anyagából. Ed. É. Cs. Balogh-K. P. Fischl. MFMÉ-Monumenta archaeologica 1. Szeged 2010, 71-175

= K. P. FisCHL-V. KISS-G. KulCSÁR-V. SZEVERÉNYI: Transformations in the Carpathian Basin around 1600 BC. In: 1600 BC - Cultural Change in the Shadow of the Thera-Eruption? Ed. H. Meller. Halle, in press.

$=$ S. FORENBAHER: Radiocarbon dates and absolute chronology of the Central European Early Bronze Age. Antiquity 67 (1993) 218-220, 235-256.

$=$ Fl. GogÂltan: Early and Middle Bronze Age chronology in South-West Romania. General aspects. In: The Early and Middle Bronze Age in the Carpathian Basin. Proceedings of the International Symposium in Alba Iulia, 24-28 September 1997. Ed. H. Ciugudean, Fl. Gogâltan. Bibliotheca Musei Apulensis 8. Alba Iulia 1998, 191-212. 
GOGÂLTAN 1999

GoGÂLTAN 2005

GOGÂLTAN 2008

GÖRSDORF 1992

GÖRSDORF-MARKOVÁ-FURMÁNEK 2004

HORVÁTH 2004a

HORVÁTH 2004b

ILON 1999

ILON 2007

JAEGER 2010

JAEGER 2011

KADA 1909

KALICZ-SCHREIBER 1995a

KALICZ-SCHREIBER 1995 b

KeLeTI-LAKATOS-MaKKai 1965

Koós 2002

KoÓs 2009

Koós 2010

KovÁCS 1963

KovÁCS 1973

KovÁCS 1982

KovÁCS 1984

KREITER 2007
= Fl. GoGÂLtAN: Bronzul timpuriu şi mijlociu românesc şi pe cursul inferior al Mureşului. Chronologia şi descoperilie de metal (Die frühe und mittlere Bronzezeit in rumänischen Banat und am Unterlauf der Marosch. Die Chronologie und die Metallfunde). Bibliotheca historica et archaeologica Banatica 23. Timişoara 1999.

= Fl. GogÂLTAN: Der Beginn der bronzezeitlichen Tellsiedlungen im Karpatenbecken: Chronologische Probleme. In: Interpretationsraum Bronzezeit. Bernhard Hänsel von seinen Schülern gewidmet. Hrsg. B. Horejs, R. Jung, E. Kaiser, B. Teržan. UPA 121. Bonn: Habelt 2005, 161-179.

= Fl. GogÂLtan: Fortified Bronze Age tell settlements in the Carpathian Basin. A general overview. In: Defensive Structures from Central Europe to the Aegean in the $3^{\text {rd }}$ and $2^{\text {nd }}$ Millenium BC. Ed. J. Czebreszuk, S. Kadrow, J. Müller. Studien zur Archäologie in Ostmitteleuropa 5. Poznań-Bonn 2008, 39-56.

= J. GÖRSDORF: Interpretation der ${ }^{14} \mathrm{C}$-Datierungen im Berliner Labor an Materialien eines Hauses von Feudvar bei Mošorin in der Vojvodina. Germania 70/2 (1992) 279-291.

J. Görsdorf-K. Marková-V. FurmáneK: Some new ${ }^{14} \mathrm{C}$ data to the Bronze Age in the Slovakia. Geochronometria. Journal on Methods and Applications of Absolute Chronology 23 (2004) 79-91.

= T. HoRvÁTH: A vatyai kultúra településeinek kőanyaga. Komplex régészeti és petrográfiai feldolgozás [The lithic material of the settlements of the Vatya culture. Complex archaeological and petrographic analysis]. Unpublished PhD Thesis, Eötvös Loránd University Budapest 2004.

= T. HorvÁTH: Néhány megjegyzés a vatyai kultúra fémmüvességéhez - technológiai megfigyelések a kultúra kőeszközein (Die Metallkunst der Vatya-Kultur - technologische Beobachtungen an ihren Steingeräten). CommArchHung 2004, 11-64.

= G. ILON: A bronzkori halomsíros kultúra temetkezései Nagydém-Középrépáspusztán és a hegykői edénydepot (Die Bestattungen der bronzezeitlichen Hügelgräberkultur in Nagydém-Középrépáspuszta und das Gefässdepot von Hegykő). Savaria 24/3 (1998-1999 [1999]) 239-276.

= G. ILON: Houses of the Late Tumulus/Early Urnfield culture. Based on the excavations at Németbánya. Ôsrégészeti Levelek/Prehistoric Newsletter 7 (2005 [2007]) 135-145.

= M. JAEGER: Transkarpackie kontakty kultury Otomani-Füzesabony (The Trans-Carpathian contacts of the Otomani-Füzesabony culture). In: Transkarpackie kontakty kulturowe w epoce kamienia, brązu i wczesnej epoce żelaza. Ed. J. Gancarski. Krosno 2010, 313-329.

$=$ M. JAEGER: Central European Societies of Fortified Settlements in the First Half of the $2^{\text {nd }}$ Millenium BC. Comparative study of trial areas. Unpublished PhD manuscript, Adam Mickiewicz University in Poznań 2011.

= E. KADA: Bronzkori urnatemető Vatyán (Pest m.) (Bronzezeitliches Urnengräberfeld von Vatya, Kom. Pest). ArchÉrt 29 (1909) 124-130.

= R. KALICZ-SCHREIBER: Bronzkori urnatemető Szigetszentmiklós határában (Das bronzezeitliche Urnengräberfeld von Szigetszentmiklós). Ráckevei múzeumi füzetek 2. Ráckeve 1995.

$=$ R. KALICZ-SCHREIBER: Siedlungsformen der frühbronzezeitlichen Nagyrév-Kultur im westlichen Mittelungarn. In: Settlement Patterns between the Alps and the Black Sea, $5^{\text {th }}$ to $2^{\text {nd }}$ Millennium B.C. Ed. A. Aspes. Memorie del Museo Civico di Storia Naturale di Verona IIa, 4. Verona-Milano 1995, $133-140$.

= F. Keleti-E. Lakatos-L. Makkai (eds): Pest megye múltjából. Tanulmányok [From the Past of County Pest. Studies]. Pest megye múltjából 1. Budapest 1965.

= J. Koós: Bronzezeitliche Siedlungsforschungen in Nordostungarn. BudRég 36 (2002) 221-233.

= J. Koós: Bronzezeitliche Siedlung in Nordostungarn und die Koszider-Problematik. In: Bronze Age Communities in the Carpathian Basin. Proceedings of the International Colloquium from Târgu Mureş 24-26 October 2008. Ed. S. Berecki, E. R. Németh, B. Rezi. Cluj-Napoca 2009, 79-89.

= J. Koós: A füzesabonyi kultúra települése Nagyrozvágyon (Settlement of the Füzesabony culture at Nagyrozvágy). HOMÉ 49 (2010) 35-44.

= T. KovÁcs: Jelentés az Aba-Belsőbáránd-Bolondváron végzett 1960. évi ásatásról (Report). Alba Regia 2-3 (1961-62 [1963]) 131-136.

= T. KovÁcs: Representations of weapons on Bronze Age pottery. FolArch 24 (1973) 7-31.

= T. KovÁcs: Befestigungsanlagen um die Mitte des 2. Jahrtausends v. u. Z. in Mittelungarn. In: Beiträge zum bronzezeitlichen Burgenbau in Mitteleuropa. Hrsg. B. Chropovský, J. Herrmann. Berlin-Nitra 1982, 279-291.

= T. KovÁcs: Vatya-Kultur. In: Kulturen der Frühbronzezeit des Karpatenbeckens und Nordbalkans. Hrsg. N. Tasić. Balcano-Pannonica, Sonderausgabe 22. Beograd 1984, 217-233.

= A. KreITER: Technological Choices and Material Meanings in Early and Middle Bronze Age Hungary. Understanding the active role of material culture through ceramic analysis. BAR IntSer 1604. Oxford 2007. 
KULCSÁR 1995a

KULCSÁR 1995b

KULCSÁR 1997

KULCSÁR 2008

KULCSÁR 2011

MAROSI-SOMOGYI 1990

MEIER-AREndt 1992

MIKLÓs 1982

MiKLÓs 2007a

MiKLós 2007b

MiKLÓs 2008

MiKLÓs 2010

Mozsolics 1957

MozSOLICS 1967

MozSOLICS 1988

NovÁKI 1952

Novotná 1998

PÉCSI 1959

F. Petres-BÁNDI 1969

PoROSZLAI 1988

PoROSZlai 1991a

PorosZlai 1991b

PorosZlai 1992a

Poroszlai 1992b

Poroszlai 1992c

PoROSZLAI 1996

POROSZlaI 1999-2000
= G. KuLCSÁR: Régészeti emlékek Inárcson és környékén [Archaeological finds and sites at Inárcs area]. In: Inárcs története 1263-1993 [The History of Inárcs 1263-1993]. Ed. L. Czagányi. Inárcs 1995, 41-81.

= G. KulcsÁR: Kakucs-Balla-domb. A Vatya-kultúra réteges települése [Kakucs-Balla-domb. A multi-layer settlement of the Vatya culture]. Unpublished MA Thesis, Eötvös Loránd University. Budapest 1995.

= G. KulCSÁR: Előzetes jelentés Kakucs-Balla-domb középső bronzkori tell-településének leletmentő ásatásáról 1992-1993 (Adatok Dél-Pest megye bronzkori településtörténetéhez) [Preliminary report about the rescue excavation at Kakucs-Balla-domb in 1992-1993]. Pest megyei múzeumi füzetek 4. Szentendre 1997, 343-353.

= G. KulCSÁR: Középső bronzkori tell település Kakucs-Balla-dombon [Middle Bronze Age tell settlement at Kakucs-Balla-domb]. In: Képek a múltból. Az elmúlt évek ásatásai Pest megyében [Pictures from the Past. Last years excavations in County Pest]. Ed. K. Ottományi. Szentendre 2008, 39.

= G. KulcSÁR: Untangling the Early Bronze Age in the Middle Danube Valley. In: Ten Thousand Years along the Middle Danube. Life and early communities from Prehistory to history. Ed. Gy. Kovács, G. Kulcsár. VAH 26. Budapest 2011, 179-210.

= S. MARosi-S. SomogYI (eds): Magyarország kistájainak katasztere [Cadastre of the Small-Landscapes in Hungary]. MTA Földrajztudományi Kutató Intézet. Budapest 1990.

= A. MeIER-Arendt (Hrsg.): Bronzezeit in Ungarn. Forschungen in Tell-Siedlungen an Donau und Theiss. Frankfurt a.M. 1992, 48-65.

= Zs. MikLós: A Gödöllői-dombvidék várai [Fortified Settlements and Castles in the Gödöllő Hills]. Múzeumi füzetek 21. Aszód 1982.

= Zs. MiKLós: Tolna megye várai [Castles in County Tolna]. VAH 22. Budapest 2007.

= Zs. MikLós: Légi régészeti kutatások 2006-ban (Aerial archaeological investigations in 2006). In: Régészeti kutatások Magyarországon 2006 (Archaeological Investigations in Hungary 2006). Ed. J. Kisfaludi. Budapest 2007, 137-146.

= Zs. MikLós: Légi régészeti kutatások 2007-ben (Aerial archaeological investigations in 2007). In: Régészeti kutatások Magyarországon 2007 (Archaeological Investigations in Hungary 2007). Ed. J. Kisfaludi. Budapest 2008, 145-154.

= Zs. MiKLós: Légi régészeti kutatások 2009-ben (Aerial archaeological investigations in 2009). In: Régészeti kutatások Magyarországon 2009 (Archaeological Investigations in Hungary 2009). Ed. J. Kisfaludi. Budapest 2010, 113-124.

= A. Mozsolics: Archäologische Beiträge zur Geschichte der großen Wanderung. ActaArchHung 8 (1957) 119-156.

= A. Mozsolics: Bronzefunde des Karpatenbeckens. Depotfundhorizonte von Hajdúsámson und Kosziderpadlás. Budapest 1967.

= A. Mozsolics: Der Bronzefund aus der oberen Remete-Höhle. ActaArchHung 40 (1988) 27-64.

= Gy. Nováki: Fejér megye őskori földvárai [Prehistoric fortified settlements in County Fejér]. ArchÉrt 79 (1952) 3-19.

= M. NovotnÁ: Zur Chronologie der Bronzehortfunde im Karpatenbecken. In: Tradition und Innovation. Festschrift für Christian Strahm. Ed. B. Fritsch, M. Maute, I. Matuschik, J. Müller, C. Wolf. Internationale archäologie-Studia honoraria 3. Rahden/Westf. 1998, 349-369.

= M. PÉCSI: A magyarországi Duna-völgy kialakulása és felszinalaktana (Entwicklung und Morphologie des Donautales in Ungarn). Földrajzi monográfiák. Budapest 1959.

= É. F. PETRES-G. BÁNDI: Ásatás Lovasberény-Mihályváron (Excavations at Lovasberény-Mihályvár). ArchÉrt 96 (1969) 170-177.

= I. PoROSZLAI: Preliminary report about the excavation at Nagykőrös-Földvár (Vatya culture): Stratigraphical data and settlement structure. CommArchHung 1988, 29-38.

= I. Poroszlai: Bronzkori lelőhely ásatása Dabason (Excavation at a Bronze Age site: Dabas [PestCounty]). StComit 21 (1991) 149-170.

= I. PoROsZLAI: Comparative stratigraphical study of Hungarian Bronze Age tell-settlements. In: Actes du XIII. Congrès International des Sciences Préhistoriques. Ed. J. Pavúk. Bratislava 1991, 59-67.

= I. PoroszlaI: Bölcske-Vörösgyürü (Vörösgyír). In: MeIER-ArEndT 1992, 141-145.

= I. Poroszlai: Százhalombatta-Földvár. In: MEIER-ARENDT 1992, 153-155.

= I. Poroszlai: Nagykőrös-Földvár. In: MEIER-ARENDT 1992, 156-158.

= I. PoroszlaI: Ásatások a százhalombattai bronzkori földvárban (1989-1993) (Excavations in the Bronze Age earthwork in Százhalombatta between 1989 and 1993). In: Ásatások Százhalombattán 1989-2005 (Excavations at Százhalombatta 1989-1995). Ed. I. Poroszlai. Százhalombatta 1996, $5-15$.

= I. PorosZlaI: Die Grabungen in der Tell-Siedlung von Bölcske-Vörösgyürü (Kom. Tolna) (19651967). ActaArchHung 51 (1999-2000) 111-145. 
PoROSZLAI 2000

POROSZLAI 2003a

Poroszlai 2003b

PoROSZLAI-VICZE 2000

PoROSZlaI-VICZE 2004

POROSZLAI-VICZE 2005

QUITTA-KoHL 1969

RACZKY-HERTELENDI-HORVÁTH 1992

REMÉNYI 2005

REMÉNYI 2012

ROEDER 1992

SomoGYI 2007

SÜMEGI-BODOR 2000

SÜMEGI-BODOR 2005

SZATHMÁRI 1996

\section{G. SZÉNÁSZKY 1977}

SZEVERÉNYI in press

SZEVERÉNYI-KULCSÁR 2012

UHNÉR 2010

VÁCZI-STIBRÁNYI 2008

VERES 2007

VERES-SÜMEGI-TÖRŐCSIK 2011

VICZE 1985

VICZE 1986
= I. PoroszlaI: Excavation campaigns at the Bronze Age tell site at Százhalombatta-Földvár. I. 1989-1991; II. 1991-1993. In: POROSZLAI- VICZE 2000, 13-73.

$=$ I. PoroszlaI: Fortified centres along the Danube. In: Hungarian Archaeology at the Turn of the Millenium. Ed. Zs. Visy. Budapest 2003, 151-155.

= I. PoroszlaI: The Koszider period. In: Hungarian Archaeology at the Turn of the Millenium. Ed. Zs. Visy. Budapest 2003, 161.

= I. PoroszlaI-M. Vicze (eds): SAX. Százhalombatta Archaeological Expedition. Annual report 1: Field Season 1998. Százhalombatta 2000.

= I. PorosZlAI-M. VICZE: Methodological background of a modern tell excavation in Hungary: SAX Project: Százhalombatta Archaeological Expedition. In: Einflüsse und Kontakte alteuropäischer Kulturen. Festschrift für Jozef Vladár zum 70. Geburtstag. Ed. J. Bátora J., V. Furmánek, L. Veliačik. Nitra 2004, 231-240.

= I. PoroszlaI-M. Vicze (eds): SAX. Százhalombatta Archaeological Expedition. Annual report 2: Field Seasons 2000-2003. Százhalombatta 2005.

= H. QUiTTA-G. KoHL: Neue Radiocarbondaten zum Neolithikum und zur frühen Bronzezeit Südosteuropas und der Sowjetunion. ZfA 3 (1969) 223-255.

= P. RACZKY-E. HERTELENDI-F. HoRVÁTH:Zur absoluten Datierung der bronzezeitlichen Tell-Kulturen in Ungarn. In: MEIER-ARENDT 1992, 42-47.

$=$ L. REMÉNYI: The golden age of the Carpathian Basin and the beautiful warrior. In: Gender Locales and Local Genders in Archaeology. Ed. T. Hjørungdal. BAR IntSer 1425. Oxford 2005, 1-11.

$=$ L. REMÉNYI: The defensive settlements of the Vatya culture and the Central European Bronze Age exchange system. In: Enclosed Space-Open society. Contact and Exchange in the Context of Bronze Age Fortified Settlements in Central Europe. Ed. M. Jaeger, J. Czebreszuk, K. P. Fischl. Studien zur Archäologie in Ostmitteleuropa 9. Poznań-Bonn 2012, 275-286.

$=$ M. RoEDER: ${ }^{14} \mathrm{C}$-Daten und archäologischer Befund am Beispiel eines Hauses von Feudvar bei Mošorin in der Vojvodina. Germania 70 (1992) 259-277.

= S. Somogyi: Pest megye természetföldrajzi adottságai és azok átalakulása a társadalmi élet kezdeteitől [Geographical givens and their transformations in County Pest from the beginnings of history]. In: Pest megye monográfiája. I/1: A kezdetektől a honfoglalásig [Monograph of County Pest. I/1: From the Prehistory to the Hungarian Conquest]. Ed. G. Fancsalszky, I. Torma. Pest megye régészeti emlékei. Budapest 2007, 9-40.

$=$ P. SÜMEGI-E. BODOR: Sedimentological, pollen and geoarchaeological analysis of core sequence at Tököl. In: POROSZLAI-VICZE 2000, 83-97.

$=$ P. SÜMEGI-E. BodoR: Geoarchaeological and archaeobotanical investigations in the valley of the Benta (Békás) creek. In: PorosZlaI-VICZE 2005, 209-235.

$=$ I. SzATHMÁRI: Bronze wire and sheet ornaments of the Vatya culture. In: Studien zur Metallindustrie im Karpatenbecken und den benachbarten Regionen. Festschrift für Amália Mozsolics zum 85. Geburtstag. Hrsg. T. Kovács. Budapest 1996, 75-88.

= J. G. SzÉNÁsZKY: A vatyai kultúra leletei Csongrád környékén (Die Funde der Vatya-Kultur in der Umgebung von Csongrád). ArchÉrt 104 (1977) 18-46.

= V. SzEVERÉNYI: Kora és középső bronzkori településrészletek Gyál 7., Vecsés 4. és Vecsés 113. lelőhelyeken (Early and Middle Bronze Age Settlements at Gyál 7, Vecsés 4 and Vecsés 113 sites). In press.

= V. SzeVERÉNYI-G. KulCSÁR: Middle Bronze Age settlement and society in Central Hungary. In: Enclosed Space-Open society. Contact and Exchange in the Context of Bronze Age Fortified Settlements in Central Europe. Ed. M. Jaeger, J. Czebreszuk, K. P. Fischl. Studien zur Archäologie in Ostmitteleuropa 9. Poznań-Bonn 2012, 287-351.

= C. UHNÉR: Makt och samhälle. Politisk ekonomi under bronsåldern i Karpaterbäckenet. Gotarc series B 54. Göteborg 2010.

= G. VÁCZI-M. STIBRÁNYI: Neue Erdburgen der Vatya-Kultur im Komitat Fejér. Alba Regia 37 (2008) 205-212.

= Zs. VERES: Az ócsai Selyemrét régészeti geológia vizsgálata [Archaeogeological Investigations at Ócsa-Selyemrét]. OTDK paper. University of Szeged 2007.

= Zs. VERES-P. SÜMEGI-T. TÖRŐCSIK: Az ócsai láp archeomalakológiai vizsgálata $-\mathrm{A}$ Pomatias ele gans első radiokarbon adatokkal korolt holocén előfordulása Magyarországon (First radiocarbondated Holocene record of Pomatias elegans in Hungary - Results of complex archeomalacological investigations from the Marshland of Ócsa). Archeometriai Mühely 2011/2, 181-196.

= M. ViCZE: The Bronze Age cemetery of Szalkszentmárton-Cifrahíd. In: Internationale archäologische Studentenkonferenz. Budapest 1985, 87-92.

= M. VICZE: Bács-Kiskun megye középső bronzkori urnatemetői [Middle Bronze Age urn cemeteries in County Bács-Kiskun]. Unpublished MA Thesis, Eötvös Loránd University Budapest 1986. 
VICZE 1992a

VICZE 1992b

VICZE 2000

VICZE 2004

VICZE 2011

VICZE 2013

VICZE-EARLE-ARTURSSON 2005

VICZE-CZAJLIK-TÍMÁR 2005
= M. VICZE: Die Bestattungen der Vatya-Kultur. In: MEIER-AREndT 1992, 92-95.

= M. VICZE: Baracs-Földvár. In: MEIER-ARENDT 1992, 146-148.

= M. VICZE: Background information to the field-survey. In: POROSZLAI-VICZE 2000, 119-129.

= M. VICZE: A Százhalombatta Projekt által alkalmazott ásatási technika (Excavation methodology on the Százhalombatta Project). In: Régészeti kutatások Magyarországon 2002 (Archaeological Investigations in Hungary 2002). Ed. J. Kisfaludi. Budapest 2004, 131-146.

= M. ViCZE: Bronze Age Cemetery at Dunaújváros-Duna-dülö. DissPann 4.1. Budapest 2011.

= M. VICZE: Middle Bronze Age households at Százhalombatta-Földvár. In: Moments in Time: Papers Presented to Pál Raczky on His $60^{\text {th }}$ Birthday. Ed. A. Anders, G. Kulcsár with G. Kalla, V. Kiss, G. V. Szabó. Ösrégészeti tanulmányok/Prehistoric studies I. Budapest 2013, 757-769.

= M. Vicze-T. Earle-M. Artursson: Bronze Age Site Gazetteer: Benta Valley, Hungary. In: PoroszLAI-VICZE 2005, 237-250.

= M. VicZe-Z. CZAJLIK-L. TímÁR: Aerial and topographical research of the Benta Valley. In: PoroszLAI-VICZE 2005, 251-254.

\section{APPENDIX}

Radiocarbon dates presented in the study. The dates were calibrated using the OxCal v4.1.7 programme and the IntCal09 calibration curve (https://c14.arch.ox.ac.uk/oxcal/OxCal.html) (after RACZKY-HERTELENDI-HoRVÁTH 1992; ForENBAHER 1993; GÖRSDORF-MARKOVÁ-FuRMÁNEK 2004; Koós 2009; KoÓs 2010; JAEGER 2010; JAEGER 2011; UHNÉR 2010)

\begin{tabular}{|c|c|c|c|}
\hline Site & Lab. No. & Date BP & Cal BC \\
\hline Bölcske-Vörösgyír & Bln-1646 & $3620 \pm 40$ & $\begin{array}{l}2031-1927(68.2 \%) \\
2131-1886(95.4 \%)\end{array}$ \\
\hline Bölcske-Vörösgyír & Bln-1681 & $3410 \pm 60$ & $\begin{array}{l}1865-1625(68.2 \%) \\
1884-1536(95.4 \%)\end{array}$ \\
\hline Érd & LuS-6054 & $3585 \pm 50$ & $\begin{array}{l}2022-1885(68.2 \%) \\
2126-1772(95.4 \%)\end{array}$ \\
\hline Érd & LuS-6063 & $3550 \pm 50$ & $\begin{array}{l}1956-1776(68.2 \%) \\
2024-1750(95.4 \%)\end{array}$ \\
\hline Érd & LuS-6055 & $3535 \pm 50$ & $\begin{array}{l}1939-1775(68.2 \%) \\
2021-1741(95.4 \%)\end{array}$ \\
\hline Érd & LuS-6062 & $3475 \pm 50$ & $\begin{array}{l}1880-1743(68.2 \%) \\
1932-1682(95.4 \%)\end{array}$ \\
\hline Érd & LuS-6061 & $3460 \pm 50$ & $\begin{array}{l}1878-1695(68.2 \%) \\
1907-1639(95.4 \%)\end{array}$ \\
\hline Érd & LuS-6056 & $3320 \pm 45$ & $\begin{array}{l}1662-1529(68.2 \%) \\
1733-1500(95.4 \%)\end{array}$ \\
\hline Érd & LuS-6060 & $3310 \pm 45$ & $\begin{array}{l}1635-1523(68.2 \%) \\
1731-1495(95.4 \%)\end{array}$ \\
\hline Érd & LuS-6057 & $3280 \pm 50$ & $\begin{array}{l}1616-1501(68.2 \%) \\
1682-1451(95.41 \%)\end{array}$ \\
\hline Érd & LuS-6058 & $3255 \pm 45$ & $\begin{array}{l}1608-1460(68.2 \%) \\
1632-1431(95.4 \%)\end{array}$ \\
\hline Dunaújváros-Kosziderpadlás & Bln-341 & $3505 \pm 80$ & $\begin{array}{l}1937-1740(68.2 \%) \\
2035-1624(95.4 \%)\end{array}$ \\
\hline Dunaújváros-Kosziderpadlás & GrN-1944 & $3270 \pm 50$ & $\begin{array}{l}1614-1496(68.2 \%) \\
1668-1436(95.4 \%)\end{array}$ \\
\hline Füzesabony-Öregdomb & Bln-1904 & $3450 \pm 55$ & $\begin{array}{l}1877-1691(68.2 \%) \\
1903-1625(95.4 \%)\end{array}$ \\
\hline Füzesabony-Öregdomb & Bln-1905 & $3420 \pm 50$ & $\begin{array}{l}1866-1639(68.2 \%) \\
1883-1613(95.4 \%)\end{array}$ \\
\hline Jászdózsa-Kápolnahalom & Bln-1847 & $3469 \pm 50$ & $\begin{array}{l}1879-1740(68.2 \%) \\
1921-1666(95.4 \%)\end{array}$ \\
\hline
\end{tabular}




\begin{tabular}{|c|c|c|c|}
\hline Site & Lab. No. & Date BP & Cal BC \\
\hline Jászdózsa-Kápolnahalom & Bln-1846 & $3450 \pm 58$ & $\begin{array}{l}1877-1691(68.2 \%) \\
1916-1622(95.4 \%)\end{array}$ \\
\hline Jászdózsa-Kápolnahalom & Bln-1887 & $3390 \pm 70$ & $\begin{array}{l}1862-1541(68.2 \%) \\
1881-1523(95.4 \%) \\
\end{array}$ \\
\hline Jászdózsa-Kápolnahalom & Bln-1850 & $3330 \pm 50$ & $\begin{array}{l}1682-1533(68.2 \%) \\
1739-1501(95.4 \%) \\
\end{array}$ \\
\hline Kakucs-Balla-domb & Poz-36175 & $3230 \pm 35$ & $\begin{array}{l}1526-1449(68.2 \%) \\
1608-1430(95.4 \%) \\
\end{array}$ \\
\hline Kakucs-Balla-domb & Poz-36177 & $3315 \pm 30$ & $\begin{array}{l}1627-1532(68.2 \%) \\
1681-1521(95.4 \%) \\
\end{array}$ \\
\hline Kakucs-Balla-domb & Poz-36176 & $3510 \pm 35$ & $\begin{array}{l}1889-1772(68.2 \%) \\
1928-1744(95.4 \%)\end{array}$ \\
\hline Kakucs-Balla-domb & Poz-36178 & $3550 \pm 35$ & $\begin{array}{l}1947-1782(68.2 \%) \\
2012-1771(95.4 \%) \\
\end{array}$ \\
\hline Kakucs-Balla-domb & Poz-36202 & $3590 \pm 35$ & $\begin{array}{l}2010-1896(68.2 \%) \\
2036-1783(95.4 \%) \\
\end{array}$ \\
\hline Kakucs-Balla-domb & Poz-36203 & $3605 \pm 35$ & \begin{tabular}{|l|}
$2022-1919(68.2 \%)$ \\
$2120-1882(95.4 \%)$ \\
\end{tabular} \\
\hline Kakucs-Balla-domb & Poz-36207 & $3530 \pm 30$ & \begin{tabular}{|l}
$1918-1777(68.2 \%)$ \\
$1943-1757(95.4 \%)$ \\
\end{tabular} \\
\hline Kakucs-Balla-domb & Poz-36204 & $3605 \pm 35$ & $\begin{array}{l}2022-1919(68.2 \%) \\
2120-1882(95.4 \%) \\
\end{array}$ \\
\hline Kakucs-Balla-domb & Poz-36206 & $3470 \pm 30$ & $\begin{array}{l}1877-1744(68.2 \%) \\
1884-1694(95.4 \%) \\
\end{array}$ \\
\hline Kakucs-Balla-domb & Poz-36205 & $3565 \pm 30$ & $\begin{array}{l}1956-1881(68.2 \%) \\
2021-1777(95.4 \%)\end{array}$ \\
\hline Mende-Leányvár & Bln-1942 & $3280 \pm 45$ & $\begin{array}{l}1611-1506(68.2 \%) \\
1678-1452(95.4 \%) \\
\end{array}$ \\
\hline Nagyrozvágy-Pap-domb & Deb-15829 & $3400 \pm 40$ & $\begin{array}{l}1745-1637(68.2 \%) \\
1875-1541(95.4 \%) \\
\end{array}$ \\
\hline Nagyrozvágy-Pap-domb & Deb-14717 & $3360 \pm 40$ & $\begin{array}{l}1735-1609(68.2 \%) \\
1743-1531(95.4 \%)\end{array}$ \\
\hline Nagyrozvágy-Pap-domb & Deb-13278 & $3215 \pm 40$ & $\begin{array}{l}1516-1440(68.2 \%) \\
1607-1413(95.4 \%)\end{array}$ \\
\hline Nižná Myšl’a & Bln-2811 & $3480 \pm 50$ & $\begin{array}{l}1880-1746(68.2 \%) \\
1934-1686(95.4 \%) \\
\end{array}$ \\
\hline Nižná Myšl’a & Bln-2810 & $3300 \pm 70$ & $\begin{array}{l}1665-1500(68.2 \%) \\
1741-1436(95.4 \%) \\
\end{array}$ \\
\hline Nižná Myšl’a & Bln-2776 & $3290 \pm 100$ & \begin{tabular}{|l}
$1686-1456(68.2 \%)$ \\
$1877-1387(95.4 \%)$ \\
\end{tabular} \\
\hline Százhalombatta-Földvár & LuS-6053 & $3520 \pm 50$ & \begin{tabular}{|l|}
$1912-1771(68.2 \%)$ \\
$2010-1696(95.4 \%)$ \\
\end{tabular} \\
\hline Százhalombatta-Földvár & LuS-6050 & $3475 \pm 80$ & $\begin{array}{l}1892-1691(68.2 \%) \\
2025-1609(95.4 \%) \\
\end{array}$ \\
\hline Százhalombatta-Földvár & LuS-6046 & $3420 \pm 50$ & \begin{tabular}{|l}
$1866-1639(68.2 \%)$ \\
$1883-1613(95.4 \%)$ \\
\end{tabular} \\
\hline Százhalombatta-Földvár & LuS-6048 & $3370 \pm 50$ & $\begin{array}{l}1740-1611(68.2 \%) \\
1864-1522(95.4 \%) \\
\end{array}$ \\
\hline Százhalombatta-Földvár & LuS-6051 & $3365 \pm 50$ & $\begin{array}{l}1740-1562(68.2 \%) \\
1861-1519(95.4 \%)\end{array}$ \\
\hline Százhalombatta-Földvár & LuS-6043 & $3345 \pm 50$ & $\begin{array}{l}1689-1536(68.2 \%) \\
1746-1509(95.4 \%) \\
\end{array}$ \\
\hline Százhalombatta-Földvár & LuS-6049 & $3335 \pm 50$ & $\begin{array}{l}1683-1536(68.2 \%) \\
1740-1505(95.4 \%)\end{array}$ \\
\hline
\end{tabular}




\begin{tabular}{|c|c|c|c|}
\hline Site & Lab. No. & Date BP & Cal BC \\
\hline Százhalombatta-Földvár & LuS-6042 & $3325 \pm 50$ & $\begin{array}{l}1666-1531(68.2 \%) \\
1739-1498(95.4 \%)\end{array}$ \\
\hline Százhalombatta-Földvár & LuS-6052 & $3285 \pm 50$ & $\begin{array}{l}1619-1502(68.2 \%) \\
1686-1451(95.4 \%)\end{array}$ \\
\hline Százhalombatta-Földvár & LuS-6047 & $3265 \pm 50$ & $\begin{array}{l}1612-1495(68.2 \%) \\
1666-1433(95.4 \%)\end{array}$ \\
\hline Százhalombatta-Földvár & Bln-1941 & $3265 \pm 60$ & $\begin{array}{l}1616-1461(68.2 \%) \\
1685-1429(95.4 \%) \\
\end{array}$ \\
\hline Százhalombatta-Földvár & LuS-6044 & $3245 \pm 50$ & \begin{tabular}{|l|}
$1606-1451(68.2 \%)$ \\
$1631-1419(95.4 \%)$ \\
\end{tabular} \\
\hline Százhalombatta-Földvár & LuS-6045 & $3205 \pm 50$ & $\begin{array}{l}1520-1428(68.2 \%) \\
1610-1400(95.4 \%)\end{array}$ \\
\hline Tószeg-Laposhalom & Bln-1923 & $3490 \pm 45$ & \begin{tabular}{|l|}
$1880-1756(68.2 \%)$ \\
$1927-1691(95.4 \%)$ \\
\end{tabular} \\
\hline Včelince & Bln-5559 & $3328 \pm 30$ & $\begin{array}{l}1662-1535(68.2 \%) \\
1687-1526(95.4 \%)\end{array}$ \\
\hline
\end{tabular}

